Review

\title{
Factors in mass cultivation of microalgae for biodiesel
}

\author{
ZHU Junying, RONG Junfeng, ZONG Baoning * \\ SINOPEC Research Institute of Petroleum Processing
}

\section{A R T I C L E I N F}

\section{Article history:}

Received 28 October 2012

Accepted 1 December 2012

Published 20 January 2013

Keywords:

Microalgae

Biofuel

Photobioreactor

Lipid content

Mass cultivation

\begin{abstract}
A B S T R A C T
Biofuel from microalgae is a long term strategy to solve the energy crisis. It is a new area of biological engineering and process engineering that consists of the isolation and characterization of microalgae species, mass cultivation of microalgae, harvesting and post-processing. The successful mass cultivation of microalgae is one of its main challenges. Several factors influencing the mass cultivation of microalgae are discussed, such as microalgae species, metabolic mechanism, culture conditions and the photobioreactor. This paper will help the development of biofuels from microalgae and its photobioreactor.
\end{abstract}

(C) 2013, Dalian Institute of Chemical Physics, Chinese Academy of Sciences. Published by Elsevier B.V. All rights reserved.

\section{Introduction}

Energy is the basic driving force for the development of society and economy. The rising demand for energy threatens the availability of sustainable energy for future generations. Fossil fuel is a non-renewable resource that is getting exhausted. Developing new means of biofuel production as a renewable green energy is becoming increasing important [1,2]. The first generation of biofuels were mainly extracted from food and oil crops, which include starch and corn. The use of cellulose, such as crop stalks, as the raw material to extract biofuel is considered the second generation of biofuels. Biofuels from microalgae are considered the third generation of biofuels. It has marked advantages over the previous two generations and it has been widely studied [3-5].

The technology of biofuels from microalgae mainly comprises four areas, which are isolation and characterization of microalgae species, mass cultivation of microalgae, harvesting, and post-processing. It is a new area that integrates biological engineering and process engineering, which still needs much study. Several factors are important in the development of biofuels from microalgae, among which its mass cultivation plays a key role. Many species have a high lipid content, including Chlorophyta and Bacillariophyta, such as Chlorella, Scenedesmus, and Phaeodactylum. However, the growth rate and lipid content of microalgae under mass cultivation conditions are significantly lower than those grown in the laboratory. This may be due to that optimal conditions are provided in the laboratory, and these may not be the same in mass cultivation, thereby influencing the growth rate and lipid content. Therefore, it is very important to study how to maintain microalgae in a state of high growth rate and lipid content. The study of the factors, such as isolation of microalgae species, metabolic mechanism, culture conditions and the photobioreactor, can improve the development of biofuels from microalgae. Further studies and summaries of previously obtained results are important for optimal microalgae biomass production, optimal photobioreactor design, the development of catalysts for the conversion of lipids to biodiesel and for understanding the pollutant formation chemistry of microalgae-derived biofuels.

\footnotetext{
* Corresponding author. Tel: +86-10-82368011; E-mail: zongbn.ripp@sinopec.com

This work was supported by the National Basic Research Program of China (973 Program, 2012CB224803).

DOI: $10.1016 / \mathrm{S} 1872-2067(11) 60497-\mathrm{X}$
} 


\section{Microalgae species}

\subsection{Microalgae}

Microalgae are microscopic photosynthetic, free living organisms of several microns (Chlorella only 3-5 $\mu \mathrm{m}$ ). They thrive in diverse aquatic habitats, which include freshwater, brackish $(<3.5 \%$ salt), marine (3.5\% salt), and hypersaline ( $>3.5 \%$ salt) environments with a wide range of temperature and $\mathrm{pH}$. Algae are typically subdivided into microalgae and macroalgae according to size. Unlike microalgae, macroalgae have cells organized into structures resembling the leaves, stems, and roots of higher plants, and some are as long as $60 \mathrm{~m}$. Microalgae can also be subdivided into two broad categories: the prokaryotic cyanobacteria and the true eukaryotic microalgae. Cyanobacteria, often referred to as the blue-green algae, have chlorophyll a and do not possess chloroplasts or any other such organelles. These have a high protein content as much as $70 \%$ of dry mass and a low fat content of approximately $5 \%$ [6]. The kinds of eukaryotic microalgae are enormous and there are tens of thousands of species, such as Chlorophyta, Bacillariophyta and Xanthophyta. These are exceeding rich in lipid and protein, and are considered the main microalgae species for biofuels.

Microalgae have several advantages as a material for biofuels to replace petroleum-based fuels. Microalgae grow rapidly and many kinds are rich in lipid (20\%-50\%). The cultivation of microalgae does not entail a land conflict with agriculture for food because it can utilize wastewater and non-potable saline water that cannot be used by conventional agriculture. The fixation of $\mathrm{CO}_{2}$ by microalgal photosynthesis is one of the most promising method for $\mathrm{CO}_{2}$ sequestration from flue gas. The microalgae biomass can produce biofuels including green diesel, green gasoline, aviation fuels, ethanol, and methane as well as valuable co-products. The biochemical mechanism of photosynthesis in microalgae is similar to that in plants, but due to their simple structure, microalgae are particularly efficient converters of solar energy. They do not have support and reproductive structures, and when provided with light and nutrients, the microalgal cells can use most of the energy trapped for biomass growth.

Microalgae can either be autotrophic or heterotrophic. The former require inorganic compounds such as $\mathrm{CO}_{2}$, salts and a light energy source for growth and the latter are nonphotosynthetic [7-10]. Some microalgae are mixotroph, such as Chlorel$l a$, which has the ability to both perform photosynthesis and acquire exogenous organic nutrients. Microalgal cultivation not only provides biofuels but also provides greenhouse gas reduction as it utilizes a large amount of $\mathrm{CO}_{2}$ during the cultivation. Moreover, wastewater can be used to culture microalgae. The heterotrophic or mixotrophic growth capabilities of microalgal strains are attractive attributes since these allow them to grow both in light and in dark conditions. The addition of external carbon sources can help the growth of microalgae and the accumulation of lipids. A potentially serious disadvantage of adding an external carbon source, especially an organic carbon source, is the possibility of increased contamination by unde- sired microbes.

There are two general resources from microalgae that can be utilized: biofuels and co-products [5,11,12]. Biofuels from microalgae include lipids, $\mathrm{H}_{2}$, isoprenoids, carbohydrates, alcohols (either directly or by biomass conversion), and methane (from anaerobic digestion). Lipids, mainly in the form of triacylglycerols (TAGs), are distributed in the cell membrane and intracellular organelle membrane, and parts of these contain carbohydrates, and they are similar to petroleum. Besides lipids, co-products are also valuable. These include proteins and pigments, which can be used in many fields, e.g., pharmaceuticals (therapeutic proteins, secondary metabolites), food supplements, and materials for nanotechnology. There have been many discussions on the use of microalgae biomass to produce fuel and non-fuel co-products. In our opinion, the approach should not be inflexible. A reasonable approach to decide which fuel products and additional co-products to make is to identify the optimal microalgae species according to the environment so that cellular metabolism is geared towards the products, which simplifies the characterization and possible development for products, rather than to be fixed about the type of fuel or co-product.

\subsection{Isolation and characterization of microalgae species}

Many microalgal species are available from culture collections such as UTEX (Culture Collection of Algae at the University of Texas at Austin, Texas) with about 3000 species and CCMP (Provasoli-Guillard National Center for Culture of Marine Phytoplankton at the Bigelow Laboratory for Ocean Sciences in West Boothbay Harbor, Maine) with more than 2500 species. However, many species may have lost some of their original properties, such as mating capability or versatility due to being cultivated for several decades in the collections. Therefore, it is important to obtain versatile and robust species for mass cultivation. Further, to collect the information on cultivation and species development for the mass cultivation of microalgae, it is recommended that the isolated species be screened to develop baseline data on regional environmental variability [13]. To provide the largest possible range in metabolic versatility, new species should be isolated from a wide variety of environments ranging from freshwater, brackish waters, marine, and hypersaline environments to a soil environment, as well as from a wide variety of their symbiotic associations with other organisms. Detailed information should be available for potentially valuable new species, such as required time, specific habitat, growth conditions, germination conditions, and temporal succession. In our research, it has been found that many potentially valuable new species are not suitable for mass cultivation for biofuels, although they grow rapidly and are rich in lipid. Sinopec Group collaborates with the Chinese Academy of Sciences in the study of the microalgae including isolation and characterization of microalgae species with high growth rate and lipid content in sea water, freshwater, and coastal zone and desert areas. Some microalgae species are cultured to provide biomass for biofuels. It is also possible that genetic engineering achievements in the laboratory can be applied to these species. 
The ideal screening should cover three major areas: growth physiology, metabolite products, and species robustness. The growth physiology of microalgae encompasses a number of parameters such as maximum specific growth rate, maximum cell density, tolerance to environmental variables (temperature, $\mathrm{pH}, \mathrm{CO}_{2}$ levels, etc), and variability between in situ and laboratory performance. Screening of the metabolite products has to include not only the metabolite composition and content, but also the productivity of the cells for metabolites and the valuable cellular contents of proteins, lipids, and carbohydrates. The rapid lipid analysis of strains would be also very helpful. An ideal analytical method should be able to provide fatty acid profiles and identify neutral and polar lipids. Furthermore, metabolites excreted into the growth medium have been largely ignored, but these may prove to be valuable co-products. For the mass cultivation of a selected microalgal species, it is also important to consider robustness, which include parameters such as culture consistency, resilience, community stability, and susceptibility to predators present in a given environment. Moreover, it is necessary to perform small scale simulation of mass cultivation conditions to determine the robustness of the selected species. The project on the investigation of the technology of biofuels from microalgae carried out by Sinopec Group and the Chinese Academy of Sciences has begun the culture of microalgae in photobioreactors larger than $100 \mathrm{~L}$.

\subsection{Biosynthesis and regulation of lipids}

Triacylglycerols (TAGs) are the major source of biofuels as these are the main stored neutral compound in many microalgae under stress conditions, such as high light or nutrient starvation [14-17]. Some microalgal species naturally accumulate large amounts of TAGs (30\%-60\% of dry weight), and have photosynthetic efficiency and lipid product potential that are at least an order of magnitude higher than those of terrestrial crop plants. However, the synthesis mechanisms of fatty acids and TAGs in microalgae are not known.

The Kennedy pathway is believed to be the major pathway for the accumulation of TAGs in plants and microalgae. It involves de novo fatty acid synthesis in the stroma of plastids and subsequent incorporation of the fatty acid into the glycerol backbone, and leads to TAGs via three sequential acyl transfers from acyl CoA in the endoplasmic reticulum. The conversion of acetyl CoA to malonyl CoA, catalyzed by acetyl CoA carboxylase (ACCase), is the commitment step and also the first step in fatty acid synthesis. Thus, it has been propounded that enhancing the activity of ACCase would be helpful for the accumulation of lipids in microalgae. However, the results were different, and excessive production of ACCase, which catalyses a key metabolic step in the biosynthesis of lipid, did not lead to increased lipid content. There are several steps between the first step catalyzed by ACCase and the step of synthesizing TAGs in the Kennedy pathway, and the decreased activity of ACCase in these steps may be the reason $[18,19]$. There are several pathways for TAGs synthesis by microalgae. The relative contributions of individual pathways to overall TAGs formation depend on environmental and culture conditions. Alternative pathways that convert membrane lipids and/or carbohydrates to TAGs have been demonstrated in plants and yeast, which perform in an acyl CoA-independent way, but these have not yet been found in microalgae $[20,21]$. It is well known that fatty acids are common precursors for the synthesis of both membrane lipids and TAGs, but there are several aspects that need elucidation, including the distribution of the precursors in the two distinct destinations, the inter-conversion between the two types of lipids, and information on regulation at the genetic level.

It is a challenge to extrapolate information learned about lipid biosynthesis and regulation from laboratory species to species cultured on a large scale. It is also not known if the ability to control the fate of fatty acids varies among microalgal taxonomic groups and even between isolates or strains of the same species, that is to say, whether the basal lipid/TAGs content is an intrinsic property of individual species. Similarly, it is difficult to use information about lipid biosynthesis in plants for microalgae [22]. Thus, the study of fatty acid and lipid synthesis in order to identify the key genes/enzymes and new pathways in microalgae species is very important for biofuels, as is the study of the genes involved in lipid metabolism.

Under environmental stress conditions, such as nutrients starvation and high light, microalgae quickly stop their division and accumulate TAGs as the main storage compound [14-17]. This is almost the default pathway to synthesize and deposit TAGs to form lipid bodies in cytosol under environmental stress. The pathway of TAGs synthesis may play more active and diverse roles in response to stress. Under stress, excessive electrons that accumulate in the photosynthetic electron transport chain may induce the over-production of reactive oxygen species, which may in turn cause the inhibition of photosynthesis and damage membrane lipids, proteins and other macromolecules. The excess electrons can be consumed during the TAGs synthesis pathway. The synthesis of a C18 fatty acid consumes approximately $24 \mathrm{NADPH}$ from the electron transport chain, which is twice that required for the formation of a carbohydrate or protein molecule of the same mass. This reduces the over-produced electrons in the transport chain under high light or other stresses [23]. Conversely, the TAGs synthesis pathway is usually associated with secondary carotenoid synthesis in microalgae [24,25]. The molecules (e.g. $\beta$-carotene and lutein) produced in the pathway are sequestered in cytosolic lipid bodies, which can prevent or reduce excessive light from striking the chloroplast under stresses by peripheral distribution. TAGs synthesis can also utilize phosphatidylcholine, phatidylethanolamine and galactolipids or toxic fatty acids excreted from the membrane system as acyl donors, thereby serving as a mechanism to detoxify membrane lipids and deposit them in the form of TAGs. The nitrogen concentration influences the lipid content of microalgae. A low concentration of nitrogen reduces the protein content in microalgae and increases the lipid and carbohydrate contents. With Dunaliella tertiolecta cultured in a nitrogen-starvation medium, the accumulation of total lipid occurred on the fifth day, and was higher than in a normal medium [26]. The accu- 
mulation of lipid per cell was more in the nitrogen-starvation medium than in the normal medium, and it happened on the third day and it had achieved a maximum of more than five times by the fourth day. Although the accumulation rates were different in the two media, the composition of the lipid were almost the same [26].

Currently, near-complete genome information of some microalgal species are or will shortly become available. A large scale EST (Expressed Sequence Tag) sequencing of microalgae will provide better knowledge on genes differently expressed under different lipid production conditions to give information about photosynthetic carbon partitioning and lipid synthesis in microalgae. Based on such information, metabolic engineering through genetic manipulation represents yet another promising strategy for producing biofuels. The available approaches include random and targeted mutagenesis and gene transformation. The cloning and transforming of genes that influence lipid synthesis or improve robustness in selected microalgal species that have proven amenable to mass cultivation will enhance the overall performance and sustainable products of TAGs or other lipids. Genetic engineering can be used to regulate lipid metabolism to increase the microalgae content by enhancing the fatty acid synthesis pathway, regulating the TAGs synthetic bypass, inhibiting competitive and degradation pathways, as well as enhancing the lipid composition $[18,19,27]$. However, genome functional annotations have indicated that some aspects of TAGs accumulation and degradation pathways are species-specific and these are essentially unknown thus far. It is worth noting that the ecological security of microalgae species during genetic engineering should receive more attention.

\section{Factors influencing the growth and lipid content of microalgae}

Microalgae are potential valuable materials for biofuels. Microalgae with sequenced genomes and transgenic capabilities are suitable for studying cellular processes to provide information on the basic cellular processes and regulation involved in the synthesis of the biofuel precursors, which will be useful for the cultivation. Moreover, microalgae that can grow well in the laboratory may be suitable for large scale cultivation under different environments. However, this is not true of all microalgae. Therefore, there is uncertainty about whether the information obtained from the laboratory model species can be applied to mass cultivation outdoors. Numerous factors influence the cultivation of microalgae, including light, nutrient supply, $\mathrm{CO}_{2}, \mathrm{pH}$, temperature and $\mathrm{O}_{2}$ [28-31]. It is important to apply the factors that influence the cultivation of microalgae in the laboratory to mass cultivation outdoors. The growth rate and lipid content of microalgae have a close relationship with light, nitrogen, phosphorus, and temperature [15,32,33]. The conditions for growth and lipid accumulation are different with different species. Therefore, the optimum mass cultivation conditions to be used for microalgae should be those that increase growth rate and lipid content, which are the main factors affecting the biofuel process.

\subsection{Light}

The intensity, wavelength and frequency of light affect the photosynthetic efficiency of microalgae [34]. The light intensity is critical because microalgae grow only when the intensity is higher than the light compensation point. It is better for the light intensity to be lower than light saturation. Microalgae and plants have two photosystems: photosystem I with peak absorption at $680 \mathrm{~nm}$ and photosystem II with peak absorption at $700 \mathrm{~nm}$. The absorptivity of light with different wavelengths vary for microalgae and plants. For example, the light absorptivity order of Chlorella is red light, followed by yellow and glaucoma light [35]. Light and dark cycle also strongly influence the growth and photosynthetic efficiency of microalgae. It has been suggested that when the frequency of the light/dark cycle increases to higher than $1 \mathrm{~Hz}$, the photosynthetic efficiency of microalgae is improved [36]. This phenomena suggested that adding baffles to a flat photobioreactor helps to enhance the photosynthetic efficiency of microalgae $[37,38]$. Natural light is always used for the mass cultivation of microalgae because it is free. Solar radiation is plentiful in China. It can reach more than $280 \mathrm{~W} / \mathrm{m}^{2}$ per year for some zones and $120 \mathrm{~W} / \mathrm{m}^{2}$ per year for most zones [39]. The natural light conversion efficiency of microalgae can reach 3\%-11\%, which becomes higher under artificial conditions. Natural light has a full light spectrum, which is good for cultivation. One of the disadvantages of natural light is the difficulty of its control, and it is too high on sunny days especially at noon and too low on rainy days.

\subsection{Nutrients}

Many elements have to be provided for the growth of microalgae, such as carbon $(\mathrm{C})$, oxygen $(\mathrm{O})$, hydrogen $(\mathrm{H})$, nitrogen $(\mathrm{N})$, potassium $(\mathrm{K})$, calcium $(\mathrm{Ca})$, magnesium $(\mathrm{Mg})$, iron (Fe), sulfur (S), phosphorus (P), and trace elements. The major nutrients are carbon, oxygen, hydrogen, nitrogen, phosphorus, and potassium. The first three are obtained from water and air and the latter three have to be absorbed from the culture medium. During cultivation, N and P become limiting. They both play a role in controlling the growth ratio and lipid production of microalgae. Therefore, the ratio of $\mathrm{N}$ and $\mathrm{P}$ is often used as an important indicator, with too high a value meaning $\mathrm{P}$ restriction and too low a value showing that the supply of $\mathrm{N}$ is falling short.

Nitrogen is one of the essential elements for the growth, development, reproduction, and other physiological activities of microalgae. The nitrogen source and concentration also affect the accumulation of lipid in microalgae. Usually, ammonium salts, nitrates, urea, etc. are used as nitrogen sources, but their absorption rates and utilization are different [40]. Experiments showed the absorption and utilization of nitrogen have the following order: ammonia $>$ urea $>$ nitrate $>$ nitrite. This is because ammonia is directly used to synthesize amino acid while the other nitrogen sources have to be converted to ammonia to synthesize amino acid $[41,42]$. It also has been found that microalgae grow well with urea and nitrate. Using the nitrogen sources of urea, $\mathrm{NaNO}_{3}$ and $\mathrm{NH}_{4} \mathrm{HCO}_{3}$, the maxi- 
mum growth rate of Chlorella was found to be with urea and the maximum lipid content was found to be with $\mathrm{NaNO}_{3}$. Therefore, if the cost is not a problem, it is better to choose $\mathrm{NaNO}_{3}$ as the nitrogen source from a consideration of the productivity and lipid content [43]. On increasing the concentration of $\mathrm{N}$, the growth rate of microalgae first increased and then decreased, which indicated that a high concentration of $\mathrm{N}$ inhibited the growth rate $[43,44]$. A possible reason is that microalgae grow so fast with abundant nitrogen that $\mathrm{P}$ is depleted, and thus the ratio of $\mathrm{N}$ to $\mathrm{P}$ gets unbalanced [45]. In other researches, the maximum growth rate of Dunaliella tertiolecta was found to be at the concentration of $23 \mathrm{mmol} / \mathrm{L} \mathrm{NaNO}_{3}$ and the growth rate did not increase with the concentration up to $46 \mathrm{mmol} / \mathrm{L}$ [26]. The growth rate of Dunaliella tertiolecta was almost the same with the concentrations of $1 \mathrm{mmol} / \mathrm{L} \mathrm{NH} \mathrm{N}_{4} \mathrm{Cl}$ and $2.3 \mathrm{mmol} / \mathrm{L} \mathrm{NaNO}_{3}$ and decreased on increasing the concentration of $\mathrm{NH}_{4} \mathrm{Cl}$. Although $\mathrm{NO}_{3}{ }^{-}$has to be reduced to $\mathrm{NH}_{4}{ }^{+}$to be used by microalgae, a high concentration of $\mathrm{NH}_{4}{ }^{+}$is not suitable for growth. This which may be due to that the respiration of microalgae is adversely affected by $\mathrm{NH}_{4}{ }^{+}$in too high concentration [26].

$\mathrm{N}$-Stress can increase lipid content. This is usually applied to get more biofuels in the microalgae process. The possible reason is that the content of adenosine monophosphate deaminase (AMPD) increases under $N$-stress, enhancing the catalysis of adenosine monophosphate (AMP) to inosine monophosphate (IMP) and ammonia. Because most of isocitrate dehydrogenase (ICDH) in mitochondrion is dehydrogenase dependent on AMP, the reducing of AMP would depress or even completely inhibit the activity of ICDH [46]. Citric acid can either be catalysed to acetyl CoA by citrate lyase, or in the citric acid cycle. ICDH is an enzyme in the citric acid cycle, and the inhibition of the activity of ICDH will increase the production of acetyl CoA. Applying stress in the form of limiting nutrients, esp. $\mathrm{N}$ and $\mathrm{P}$, can increase lipid content. However, this stress application also curtails the growth ratio, and thus may lower the amount of biomass and lead to a reduced overall lipid production.

Phosphorus is another essential element for the cultivation of microalgae. Phosphate, hydrogen phosphate, and so on, play an important role in the metabolic processes of microalgae, as well as the succession of phytoplankton in aquatic ecosystems. It takes part in many metabolic processes, such as signal transduction, energy conversion and photosynthesis. The metabolic mechanisms of $\mathrm{P}$ in the different forms are different in microalgae. Orthophosphate is most easily absorbed and significantly promotes the growth of microalgae [47]. Within a range, the growth rate of microalgae increases with increasing concentration of $\mathrm{P}$, and the opposite occurs when the concentration is too high, which may be due to that the changing N/P inhibits the cell division of microalgae [48].

\section{3. $\mathrm{CO}_{2}$ and $\mathrm{pH}$}

$\mathrm{CO}_{2}$ is one of the reactants and also one of the limiting factors in the photosynthesis of microalgae and plants. The photosynthesis of microalgae requires a certain $\mathrm{CO}_{2}$ concentration, and the maximum photosynthetic efficiency is often achieved with $\mathrm{CO}_{2}$ concentrations from $1 \%$ to $5 \%$ (by volume). Increasing $\mathrm{CO}_{2}$ levels can improve photosynthetic efficiency, which is consistent with a higher $\mathrm{CO}_{2}$ concentration leading to a higher biomass of microalgae [49]. Adding $\mathrm{NaHCO}_{3}$ to the medium during the cultivation of microalgae not only supply $\mathrm{CO}_{2}$ to promote productivity, but also can be used as a buffering agent to control the $\mathrm{pH}$ [43]. The conversion efficiency of solar energy is improved by supplementing $\mathrm{CO}_{2}$ to the medium of Nitzschia closterium to provide sufficient energy for photosynthesis [50]. The photosynthesis of Nitzschia closterium is affected by a high $\mathrm{CO}_{2}$ concentration in two ways: increasing the binding of $\mathrm{CO}_{2}$ to Rubisco (Ribulose bisphosphate carboxylase oxygenase) sites thereby enhancing carboxylation, and inhibiting the photorespiration activity to increase the net photosynthetic efficiency $[49,50]$. In addition, the photosynthetic efficiency of photosystem II rises with increasing $\mathrm{CO}_{2}$ levels and more light energy is captured and transformed to chemical energy [51]. This would explain why high $\mathrm{CO}_{2}$ levels enhanced the photosynthetic efficiency of microalgae. $\mathrm{CO}_{2}$ levels in flue gases are relatively high and are able to meet the need for $\mathrm{CO}_{2}$ of microalgae. So it is very meaningful to utilize flue gases, which would reduce greenhouse gas emission as well as the cost in the economics of biofuels from microalgae. When Chlorella sp. (wild type) and its mutant were cultured with a continuous $\mathrm{CO}_{2}$-enriched gas $\left(2 \%, 10 \%\right.$ and $\left.25 \% \mathrm{CO}_{2}\right)$ and flue gas (approximately $25 \% \mathrm{CO}_{2}, 4 \% \mathrm{O}_{2}, 0.008 \% \mathrm{NO}$, and $0.009 \% \mathrm{SO}_{2}$ ), the maximum growth rate was found with Chlorella sp. (wild-type) with $2 \% \mathrm{CO}_{2}$ and the growth rate of the wild type was higher than that of the mutant [52]. It was also found that both Chlorella sp. (wild type) and its mutant grew faster with the flue gas than with the $\mathrm{CO}_{2}$-enriched gas. This was because $\mathrm{NO}$ absorbed in the medium can be converted to $\mathrm{NO}_{2}{ }^{-}$and then oxidized to $\mathrm{NO}_{3}{ }^{-}$, which can be utilized as a nitrogen source. The presence of $\mathrm{NO}_{x}$ in flue gas did not inhibit the growth of microalgae. A demonstration base with $400 \mathrm{~m}^{2}$ has been built to culture microalgae in Shijiazhuang by Sinopec Group, which directly used the flue gas from a petroleum refinery, and the cultivation of Chlorella was successful.

The $\mathrm{pH}$ is another main factor influencing the abundance of inorganic carbon (DTC). When the $\mathrm{pH}$ is below 5 , the majority of DIC is $\mathrm{CO}_{2} . \mathrm{CO}_{2}$ and $\mathrm{HCO}_{3}{ }^{-}$are equal under the condition of $\mathrm{pH}=6.6$. It is almost all $\mathrm{HCO}_{3}{ }^{-}$when the $\mathrm{pH}$ is 8.3 [53]. Therefore, the $\mathrm{pH}$ should be controlled during cultivation to enhance the absorbability and utilization of $\mathrm{CO}_{2}$ by microalgae. The $\mathrm{pH}$ can also directly affect the permeability of the cell and the hydronium forms of the inorganic salt, and indirectly influence the absorption of the inorganic salt. $\mathrm{CO}_{2}$ in the culture is consumed by the microalgae during photosynthesis, thereby increasing the $\mathrm{pH}$ of the medium. Therefore, substances like hydrochloric acid and acetic acid have to be added to control the $\mathrm{pH}$ to keep the $\mathrm{pH}$ from increasing too much to be beyond the tolerance of the microalgae. Compared with hydrochloric acid, acetic acid has the advantage that it not only adjust the $\mathrm{pH}$ value but also is used as a carbon source to enhance the growth rate of microalgae [54].

\subsection{Other factors}


Other factors like temperature and $\mathrm{O}_{2}$ are also important for the growth of microalgae. The tolerance range of temperature is different for different species. Freshwater microalgae, for instance, Chlorella and Scenedesmus, are able to adapt to the temperature in the range of $5-35{ }^{\circ} \mathrm{C}$, with the optimum temperature of $25-30{ }^{\circ} \mathrm{C}$, which should be controlled during the mass cultivation of microalgae. For microalgae and plants, $\mathrm{O}_{2}$ is the necessary gas for respiration and also the released gas from photosynthesis. Much dissolved oxygen released as a byproduct of photosynthesis is accumulated in the medium, which can lead to a high dissolved oxygen content that can threaten the survival of the microalgae. Attention should be paid to the dissolved oxygen content in the cultivation of microalgae, which can oxidize one or more enzymes and affect the electron transmission chain, and inhibit the photosynthesis process.

\section{Photobioreactors}

Photobioreactors are the critical equipment in the biofuels from microalgae process, and are one of technical bottlenecks. Before an analysis of the photobioreactor configuration, general design considerations are presented so that photobioreactor designs can be evaluated and compared effectively. The aim of photobioreactor design is to achieve optimal mass transfer, light transfer and transmission with low cost. The following aspects should be considered in the design. A growth system that rely on artificial light is not often considered because of energy efficiency and costs. A design principle for photobioreactor design is to maximize the surface area to volume ratio to provide sufficient light. How to maximize the surface area to volume ratio is the major factor considered in the designs. $\mathrm{CO}_{2}$ is necessary for photosynthesis and should be supplied in sufficient quantity for the microalgae. A high dissolved oxygen content does not favor photosynthesis, which limits the size of photobioreactors. A major disadvantage of open ponds is the loss of water to the atmosphere by evaporation, especially in water-poor areas. This problem almost does not exist in closed photobioreactors. Controlling the temperature in open photobioreactors is relatively easy due to evaporation, but this is difficult for closed photobioreactors. The cultivation location and mode have to be chosen according to the natural environmental conditions. In all cases, the design principle for photobioreactor designs is to maximize the surface to volume ratio and reduce the costs.

The common growth systems used are open and closed photobioreactors. The advantages and disadvantages of these two systems are compared in Table 1. Each system has tradeoffs between the key design parameters. The full understanding of these would help the development and innovation of photobioreactors. In practice, the energy consumption in the process is considerable, which is the core issue in the innovation of new photobioreactors. Several representative photobioreactors are discussed below.

\subsection{Open photobioreactors}

Raceway ponds are the most common open systems for
Table 1

Comparison of open and closed microalgae cultivation photobioreactor systems.

\begin{tabular}{lcc}
\hline Parameter & Open system & Closed system \\
\hline Biomass concentration & $\begin{array}{c}\text { low, } 0.1-0.5 \mathrm{~g} / \mathrm{L}, \\
\text { high harvesting costs }\end{array}$ & $\begin{array}{c}\text { high, 2-8 g/L, } \\
\text { low harvesting costs }\end{array}$ \\
Space required & high & low \\
Construction costs & low & high \\
Contamination risk & high & low \\
Water losses & high & almost none \\
$\mathrm{CO}_{2}$-losses & high & low \\
Biomass quality & difficult to control & easy to control \\
Weather dependence & high & low \\
Repeatability & low & high \\
Period of culture & long, & relatively short, \\
& approx. 6-8 weeks & approx. 2-4 weeks \\
\hline
\end{tabular}

commercial photobioreactors. They are usually constructed either as single or as groups of channels built by joining individual raceways together with a depth of $15-30 \mathrm{~cm}$. Paddlewheels are often used to drive the water continuously around the circuit to use mixing to prevent the cells from depositing, thereby increasing the exposure of the microalgae to light and $\mathrm{CO}_{2}$. Other types of mixing systems, such as pumps and airlifts, have also been proposed. Open raceway ponds were used in the treatment of industrial wastewater in the United States, Israel and other countries from the 1960s to 1970s, and were applied to culture microalgae used for health purposes, such as Spirulina, in China, the United States, and Japan from the 1980s to 1990 s $[55,56]$. Open pond raceways were the focus in the well known "Aquatic Species Program" conducted by the United States Department of Energy. The $1000 \mathrm{~m}^{2}$ ponds were located in New Mexico and good research was achieved in this test site. However, the disadvantages of open pond raceways emerge outdoors, and this should be considered in the design, mainly how this affects the factors including light and medium depth.

First of all, light is the major factor that limits the photobioreactors. Many methods have been tried to increase the exposure of the cells to light. The flow velocity is an important factor to prevent the cells from deposition to increase the exposure of microalgae to light and $\mathrm{CO}_{2}$. It is chosen based on the sinking rate of the cells and the medium depth. So the appropriate flow rates for different photobioreactors are necessary for the mass cultivation. A velocity of 10 to $30 \mathrm{~cm} / \mathrm{s}$ is found effective. Higher velocities are preferred, but it would consume too much energy [57]. Adding equipments to stir the medium is another effective method to increase the flow rate [58]. Providing additional light, especially artificial light, can enhance photosynthetic efficiency, but the energy consumption is high and very expensive. Hsieh et al. [59] employed transparent rectangular chambers (TRCs) to conduct light deep into an open tank photobioreactor to improve the photosynthetic efficiency of microalgae. This is an effective method with low cost. Figure 1 depicts the photobioreactor consisting of an open tank with different arrangements of TRCs. In this proposed photobioreactor, TRCs made of transparent acrylic provided a large area of illumination by conducting irradiance deep into the culture and redistributing light inside the tank. This increased the surface 


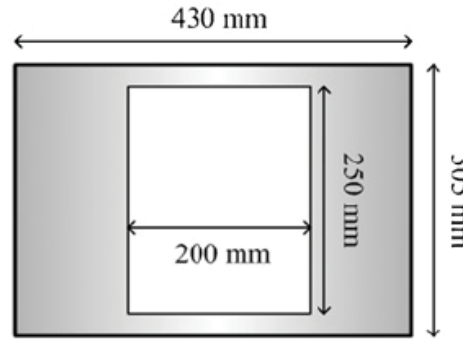

$\mathrm{TRCl}$

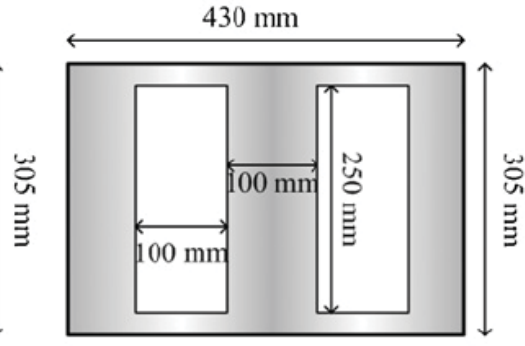

TRC2

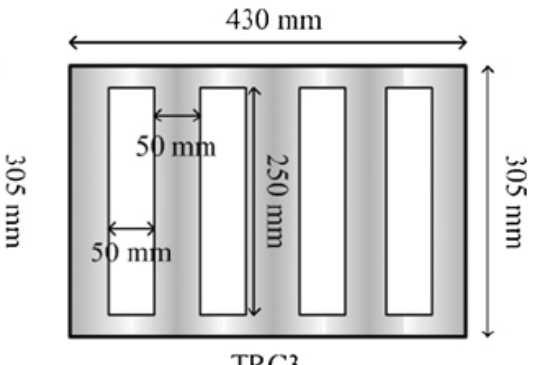

TRC3

Fig. 1. Open tank with different sizes of transparent rectangular chambers inserted [59].

area to volume ratio of the photobioreactor, and improved light utilization by the microalgae, especially at high cell density and deep depth. In our research, the TRCs were in an open tank with the same volume, shown in Fig. 1. TRC3 has the highest illumination surface-to-volume ratio and it gave the highest cell density $(3.745 \mathrm{~g} / \mathrm{L})$ and biomass productivity $(0.34 \mathrm{~g} /(\mathrm{L} \cdot \mathrm{d}))$. The total biomass from TRC 3 was 56\% more than a standard open tank system without TRCs. Many methods have been considered to enhance the light in an open pond raceway, but there are still no effective solutions.

The medium depth, which is in the range of $15-30 \mathrm{~cm}$, is another key factor influencing the mass cultivation of microalgae in open pond raceways. This has a close relationship with light transmittance. In the initial phase, the density of microalgae is low, and the light can be transported to a great depth to promote the growth and photosynthetic efficiency, which is limited by the density [60]. Enhancing the light supply is possible by reducing layer thickness. For example, a thickness of $1-10 \mathrm{~cm}$ should be present for microalgae in deep open pond raceways, which is achieved by raising the bottom by less than or equal to $5 \mathrm{~cm}$ so that a thin layer is provided [61]. The photosynthesis by the microalgae can be increased, but the proportion of the bottom raised is not clear. The depth of open pond raceways affects construction cost. With a depth less than 15 $\mathrm{cm}$, the construction and operation of large pond systems become difficult, and when this is more than $50 \mathrm{~cm}$, the cost of construction becomes prohibitive and it is very difficult to get a high cell density.

There are some other problems in the cultivation of microalgae in open pond raceways. It is difficult to control the environmental conditions including $\mathrm{CO}_{2}$, temperature, light, and $\mathrm{pH}$. For instance, the optimum light intensity of Chlorella is 4-30 $\mathrm{klx}$, but there can be up to $80-120 \mathrm{klx}$ at noon. Photoinhibition easily happens under this high intensity, especially when the density of microalgae is low. $\mathrm{CO}_{2}$ is another limiting factor but it is relatively easy to solve by bubbling. It is difficult to completely apply open pond systems to culture microalgae because these require highly selective environments due to the inherent threat of contamination and pollution from other species.

\subsection{Closed photobioreactors}

Although open systems have many advantages, they also have many problems in the mass cultivation of microalgae. Thus, closed systems have become the choice for biofuels pro- duction. The volumetric productivity in closed photobioreactors is more than 30 times higher than that in open pond raceways [62]. Owing to the higher mass productivity, harvesting costs can be significantly reduced. Numerous types of closed photobioreactors have been designed to best control the conditions in mass cultivation. These can be divided into three main categories: tubular, column, and flat plate photobioreactors. Table 2 lists some closed photobioreactors with solar and artificial radiation that have overcome some shortcomings in open photobioreactors. However, these closed photobioreactors are still not very suitable to use for mass cultivation and need more design work.

Light path is an important design factor for closed photobioreactors. In a certain range, a shorter light path leads to more productivity. As shown in Table 2, the maximum productivity was gained in the thin-layer photobioreactor with the shortest light path. Light path, which can be considered as the depth of the medium, directly affects the probability of microalgae exposure to light. Therefore, microalgae grow well where the light path is short, and slowly where the light path is long due to the severe light attenuation. Chlorophyta was cultured in photobioreactors with light paths of 3 and $6 \mathrm{~cm}$. The productivity with the $3 \mathrm{~cm}$ light path was higher by $50 \%$ than that with the light path of $6 \mathrm{~cm}$ [73]. In addition, the light path also affects the lipid content. The lipid content of microalgae cultured with the $3 \mathrm{~cm}$ light path was higher than that cultured with the $6 \mathrm{~cm}$ light path [73]. However, light intensity that is too high is not helpful for more lipid in the microalgae. When Pyramidomonas sp. and Chlorophyceae L-4 were cultured under different light intensities, the lipid content was reduced as the light intensity increased, and it decreased from $14.17 \%$ to 5.94\% for Pyramidomonas sp. and from $14.17 \%$ to $3.40 \%$ for Chlorophyceae L-4 [74]. The light path may act in two ways to affect the lipid content. One is that microalgae grow fast with a short light path, which leads to nutrition stress when there is no more supply, and thus the lipid content increases. The other is that photoinhibition often occurs under high light intensity with a short light path, which affects the growth rate and lipid content.

Several typical closed photobioreacors are discussed below.

Tubular photobioreactors can be aligned horizontally, vertically, inclined or as a helix. The diameters of the tubes are generally $2.5-5.0 \mathrm{~cm}[64,75]$. The length of the tubes depends on potential $\mathrm{O}_{2}$ accumulation, $\mathrm{CO}_{2}$ depletion and other factors, which limits the scale of tubular photobioreactors. To increase the scale, the tubes have to be arrayed horizontal fence-like, 
which improves the utilization of land but increases the operation cost. The washing of the wall of tubular photobioreactors is another difficult problem. This has a closed relationship with light permeability. At present, mechanical cleaning is the main method to do the wash. Although tubular photobioreactors have many disadvantages, they are considered suitable for outdoor mass cultivation due to a large surface area to light that can allow a high density of microalgae. The productivity reached $830 \mathrm{mg} /(\mathrm{L} \cdot \mathrm{d})$ in the works in Table 2 . In addition to the light path, other factors should be considered when designing the photobioreactor, such as the ratio of culture volume. Chlorella vulgaris was cultured in helix tubes with $3.12 \mathrm{~cm}$ diameter and straight tubes with $3.2 \mathrm{~cm}$ diameter. The maximum productivities of the helix tubes and straight tubes were 40 and $600 \mathrm{mg} /(\mathrm{L} \cdot \mathrm{d})$, respectively $[63,66]$. The light paths and culture conditions were similar in the two photobioreactors, but the maximum productivity of the straight tubes was almost 15 times higher than that of the helix tubes. This was because out of the $230 \mathrm{~L}$ culture volume, only $150 \mathrm{~L}$ was in the helix tube and under light and the rest was in the storage tank, decreasing the total productivity.

The main types of column photobioreactors are the bubbling, airlift and stirring types. They are made of transparent materials with low costs, such as glass, plastic and polyethylene $[76,77]$. Column photobioreactors are similar to the conventional fermentation tank, and the main difference is that the former needs an internal or external light. Airlift column photobioreactors use a draft tube to mix the medium. The light utilization efficiency of stirred column photobioreactors is relatively low. Column photobioreactors are generally $2-2.5 \mathrm{~m}$ high with $20-50 \mathrm{~cm}$ diameter. The simple materials used help to

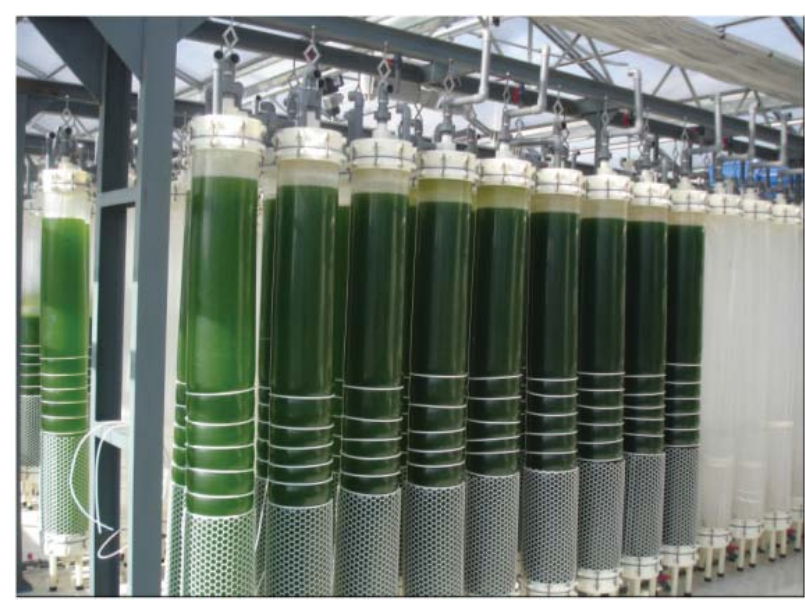

Fig. 2. Schematic of column photobioreactor.

reduce costs, and mixing by $\mathrm{CO}_{2}$ bubbling is another way to maximize $\mathrm{CO}_{2}$ capture and to reduce mixing costs. However, it is difficult to obtain a high cell density in column photobioreactors and this limits the scale. The column photobioreactors used to culture microalgae by Sinopec Group in Beijing are shown in Fig. 2. It was found that when the density is high, light limits the growth of microalgae.

Flat plate photobioreactors are horizontal or vertically aligned $[71,78]$ and is influenced by placement, light path, and dissolved oxygen concentration. They have attracted much attention due to the large surface area exposed to illumination and the high density of photoautotrophic cells observed. When flat plate photobioreactors are horizontal, the surface receives more light to enhance photosynthetic efficiency but they require more space and are liable to photoinhibition. Space and

\section{Table 2}

Textural properties of fresh CZ samples prepared by different methods.

Photobioreactor Species

Helical tubular photobioreactor, column diameter 3.12 Chlorella vulgaris $\mathrm{cm}$, culture volume $230 \mathrm{~L}, \mathrm{CO}_{2}$ supplied Chlorella emersoni

Helical tubular photobioreactor, diameter $1.6 \mathrm{~cm}$, cul- Spirulina platensis ture volume $21 \mathrm{~L}, \mathrm{CO}_{2}$ supplied

Horizontal tube, diameter $2.8 \mathrm{~cm}$, culture volume $500 \mathrm{~L}$, Scenedesmus bliquus $\mathrm{CO}_{2}$ supplied

Vertical tubular photobioreactor, $200 \mathrm{~cm}$ high, diameter Dunaliella tertiolecta $3.2 \mathrm{~cm}$, culture volume $1.4 \mathrm{~L}, \mathrm{CO}_{2}$ supplied Chlorella vulgaris

Vertical tubular photobioreactor, $63 \mathrm{~cm}$ high, diameter Anabaena variabilis $6 \mathrm{~cm}$, culture volume $0.26 \mathrm{~L}, \mathrm{CO}_{2}$ supplied

Vertical tubular photobioreactor, $75 \mathrm{~cm}$ high, diameter Aphanothece croscop$7.5 \mathrm{~cm}$, culture volume $3.0 \mathrm{~L}, \mathrm{CO}_{2}$ supplied

Vertical tubular photobioreactor, diameter $7 \mathrm{~cm}$, cul- Chlorellasp. ture volume $0.8 \mathrm{~L}, \mathrm{CO}_{2}$ supplied

Vertical column, $300 \mathrm{~cm}$ high, diameter $16 \mathrm{~cm}$, culture Chlorella sp. volume $50 \mathrm{~L}, \mathrm{CO}_{2}$ supplied

Vertical tubular photobioreactor, $36 \mathrm{~cm}$ high, diameter Chlorella sp. $10 \mathrm{~cm}$, culture volume $2 \mathrm{~L}, \mathrm{CO}_{2}$ supplied

Flat, light path $17 \mathrm{~cm}$, culture volume $60 \mathrm{~L}, \mathrm{CO}_{2}$ supplied Chlorella zofingiensis

Flat, light path $10 \mathrm{~cm}$, culture volume $200 \mathrm{~L}, \mathrm{CO}_{2}$ sup- Nannochloropsis sp. plied

Thin-layer photobioreactor, $224 \mathrm{~m}^{2}, 28 \mathrm{~m}$ long, light Chlorellasp. path $0.6-0.7 \mathrm{~cm}, \mathrm{CO}_{2}$ supplied

$\begin{array}{ccc}\text { Light } & \text { Productivity } & \text { Ref. } \\ \begin{array}{cc}\text { artificial adiation } \\ \text { artificial adiation } \\ \text { artificial adiation }\end{array} & \begin{array}{c}\text { maximum productivity, 40 mg/(L·d) } \\ \text { maximum productivity, 41 } \mathrm{mg} /(\mathrm{L} \cdot \mathrm{d})\end{array} & 63 \\ & & 64\end{array}$

solar radiation

maximum productivity, $284 \mathrm{mg} /(\mathrm{L} \cdot \mathrm{d})$; average productivity, $11.31 \mathrm{~g} /\left(\mathrm{m}^{2} \cdot \mathrm{d}\right)$

artificial adiation artificial adiation artificial adiation maximum productivity, $830 \mathrm{mg} /(\mathrm{L} \cdot \mathrm{d})$ maximum productivity, $600 \mathrm{mg} /(\mathrm{L} \cdot \mathrm{d})$ maximum productivity, $750 \mathrm{mg} /(\mathrm{L} \cdot \mathrm{d})$

artificial adiation artificial adiation artificial adiation maximum productivity, $1.9 \mathrm{~g} / \mathrm{L}$; average maximum productivity, $770 \mathrm{mg} /(\mathrm{L} \cdot \mathrm{d})$

maximum productivity, $640 \mathrm{mg} /(\mathrm{L} \cdot \mathrm{d})$

solar radiation

maximum productivity, $520 \mathrm{mg} /(\mathrm{L} \cdot \mathrm{d})$; average productivity, $360 \mathrm{mg} /(\mathrm{L} \cdot \mathrm{d})$ productivity, $111.8 \mathrm{mg} /(\mathrm{L} \cdot \mathrm{d})$ maximum productivity, $41.3 \mathrm{mg} /(\mathrm{L} \cdot \mathrm{d})$ in May

solar radiation

solar radiation maximum productivity, $58.4 \mathrm{mg} /(\mathrm{L} \cdot \mathrm{d})$ in November average productivity, $240 \mathrm{mg} /(\mathrm{L} \cdot \mathrm{d})$

average productivity, $4.3 \mathrm{~g} /(\mathrm{L} \cdot \mathrm{d})$

68

52

52

solar radiation 
Table 3

Areal and volumetric productivity of a vertical flat plate glass photobioreactor, as affected by the light path [71].

\begin{tabular}{lcc}
\hline Light path $(\mathrm{cm})$ & $\begin{array}{c}\text { Areal productivity } \\
\left(\mathrm{g} /\left(\mathrm{m}^{2} \cdot \mathrm{d}\right)\right)\end{array}$ & $\begin{array}{c}\text { Volumetric productivity } \\
(\mathrm{g} /(\mathrm{L} \cdot \mathrm{d}))\end{array}$ \\
\hline 1.3 & 5.5 & 0.846 \\
2.6 & 7.25 & 0.558 \\
5.2 & 9.25 & 0.355 \\
10.0 & 12.10 & 0.239 \\
17.0 & 10.05 & 0.118 \\
\hline
\end{tabular}

light efficiency can be improved when flat plate photobioreactors are vertically aligned, but these have to be made of high cost rigid materials. It has been considered, by analogy with solar panels, for flat plate photobioreactors to automatically tilt to the zenith angle of the sun to maximize the amount of solar radiation intercepted. However, the scalability of such systems have proved difficult. High intensity radiation has been reported to be more efficient for microalgal cultivation. Indeed, the photosynthetic efficiency of vertical flat plate photobioreactors has been higher than optimal tilt reactors, reaching the value of $20 \%$ [79]. This is due to the fact that low irradiance levels result in higher photosynthetic efficiency and the too high irradiance levels in optimal tilt reactors inhibited the photosynthesis. The light paths were in the range of $1.5-3.0 \mathrm{~cm}$, which limits the culture volume. Therefore, it is necessary to optimize the relationship among the areal productivity, volumetric productivity, and total productivity for flat plate and other photobioreactors. The length of the light path in a plate reactor determines its areal volume. The volumetric productivity was highest in the shortest light path, and lowest in the longest light path reactor, as shown in Table 3. The highest volumetric productivity was found with the shortest light path of $1.3 \mathrm{~cm}$ [71]. Volumetric productivity, therefore, has meaning only in relation to the light path. Areal productivity, in contrast, has an optimal light path at which the productivity or product is maximal. The accumulation of dissolved oxygen limits the scale of flat plate photobioreactors. Closed photobioreactors commonly make use of an external power supply to ensure sufficient mass transfer capacity. To attain the same mass transfer capacity, $53 \mathrm{~W} / \mathrm{m}^{3}$ are needed in a flat plate photobioreactor, $40 \mathrm{~W} / \mathrm{m}^{3}$ in a bubbling column and $2400-3200 \mathrm{~W} / \mathrm{m}^{3}$ in a tubular photobioreactor [80].

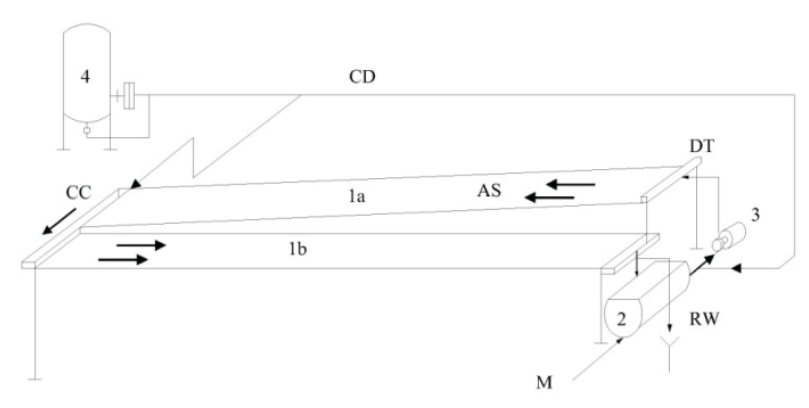

Fig. 3. Schematic of the photobioreactor. (1a, 1b) Culture area; (2) Retention tank; (3) Circulation pump; (4) $\mathrm{CO}_{2}$ storage tank. M-aeration air AS-algal suspension flow. CC-connecting channel; CD-carbon dioxide; DT-distribution tube; RW-rain water [81].
A thin layer photobioreactor is shown in Fig. 3. This photobioreactor is made of transparent materials for maximum solar energy capture, and a thin layer of dense culture flows across the culture area. Doucha et al. [81] reported that the inclination of the area was $1.1 \%-2.5 \%$, the flow velocity of the microalgae suspension was preferably $30-150 \mathrm{~cm} / \mathrm{s}$, and the thickness of the suspension was $5-18 \mathrm{~mm}$. The productivity of the microalgae Chlorella sp. was $38.2 \mathrm{~g} /\left(\mathrm{m}^{2} \cdot \mathrm{d}\right)$ or $4.3 \mathrm{~g} /(\mathrm{L} \cdot \mathrm{d})$, which was higher than those in the tubular, column, and flat plate photobioreactors. This productivity was obtained using batch feed cycles in a thin layer photobioreactor with a $224 \mathrm{~m}^{2}$ culture area (length $28 \mathrm{~m}$, slope 1.7\%), and a 6-7 mm layer of culture $[72,82]$. The layer of culture is thin, so the area for $\mathrm{CO}_{2}$ mass transfer is very important, esp. with the use of flue gas. To minimize the loss of dissolved $\mathrm{CO}_{2}$ in the microalgal suspension, a retention tank and distribution tube with a thick layer should supply $\mathrm{CO}_{2}$. The productivities presented in the researches indicated good prospect for using thin layer culture technology for the production of biomass as a feedstock for biofuels. However, there are still some shortcomings hindering the development of the thin layer photobioreactor. For example, due to the thinness of the layer, photoinhibition of microalgae easily happens when the density is not high, and the total culture volume is low. The concept of the use of a thin layer to culture a high concentration of microalgae is a new design for a photobioreactor. Rong et al. [83] invented a photobioreactor to culture microalgae that included collecting tank, conveying equipment, and culture area. In this photobioreactor, the medium flow through the culture area with a thin layer, and it is suitable for the growth of high density microalgae on a large scale and low costs. Cong et al. [61] devised an equipment that provides a thin layer for the photobioreactor with a thick layer like open pond raceways, thereby photosynthetic efficiency and productivity were increased. A patent by Gorny et al. [84] in 2011 and exhibited in Fig. 4 provided a flow-through photobioreactor containing at least one thermoplastic multi-wall, and one inner and two or more end caps. The medium flowed in the multi-wall sheets with high photosynthetic efficiency. UV light from the sun was filtered out by the reactor walls, the temperature was controlled, water in the system did not evaporate, and $\mathrm{CO}_{2}$ from flue gas can be fed to increase the yield.

A variety of closed photobioreactors were introduced above, which can overcome the limitations of open pond raceways.

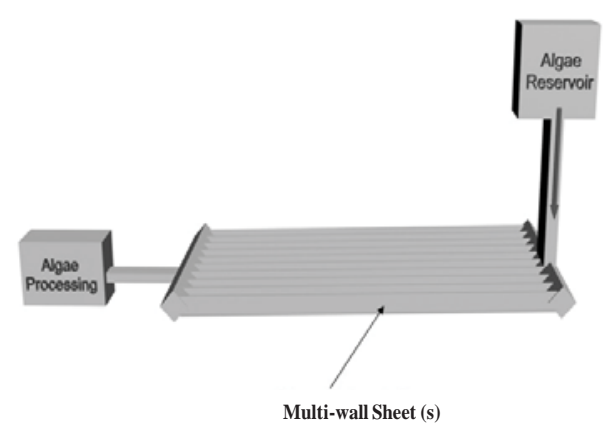

Fig. 4. Scheme of flow-through thermoplastic multi-wall sheet photobioreactor [84]. 
However, there are still some drawbacks to culturing microalgae on a large scale. The photobioreactors to culture microalgae for biofuels products require high biomass productivity per area and minimal costs. The best reactor type should have simple structure, easy operation, low costs, low energy consumption and that can be adapted to the local environment.

\subsection{Combinations of open and/or closed systems}

Some investigators have suggested that combinations of open and/or closed systems are the most effective configuration for mass cultivation. The combinations can be between open and/or closed systems, and between autotrophic and heterotrophic cultivation. Open pond raceways can provide abundant microalgae with a low density, which is then cultured in closed photobioreactors at a high density. Two stage processes are used to increase the productivity and lipid content of the microalgae. A high cell density is obtained in the first step in closed photobioreactors with a controlled environment. Next, the microalgae are exposed to nutrient deprivation by being transferred to open systems to increase the lipid content. Han et al. [85] combined open and closed systems, which included three reactors from the inside to the outside. The inside was a closed photobioreactor with artificial light to keep microalgae in the exponential growth phase. The next was an open photobioreactor with artificial or solar radiation to culture microalgae from the inside reactor. The outside was used to increase the lipid content under nutrient stress. Liu et al. [86] used a similar combination of open pound raceway and flat plate photobioreactor (or bubbling column), in which the biomass of Nannochloropsis was increased by 75\%. The capital and operating costs for the combined systems are likely to be significantly higher than for one reactor, as well as the land requirements.

\subsection{Computational fluid dynamics}

To improve the development of photobioreactors, the challenge is the efficient design of large scale production facilities. Computational fluid dynamics (CFD) is attractive for the design of optimal large and integrated systems, by making it possible to estimate the productivities of the photobioreactor before conducting cultivation experiments. There is no need to construct a number of actual photobioreactors. However, there are still more aspects that have to be incorporated in the model, such as temperature change and the concentrations of $\mathrm{CO}_{2}$ and nutrients. Sato et al. [87] applied a computer model system to evaluate the effects of the amounts of emitted $\mathrm{O}_{2}, \mathrm{CO}_{2}$ fixation amount and the growth curve of microalgae, and obtained the optimal culture conditions. Slegers et al. [88] gave more evidence for the validity of the simulation. To investigate the effect of location, variable sunlight, and reactor layout on biomass production in single standing and parallel positioned flat panels, a model approach was used to predict the yearly production of Phaeodactylum tricornutum and Thalassiosira pseudonana in the Netherlands, France, and Algeria. The model approach found that vertically placed and east-west orientated single panels produced the most biomass and shading and diffused light penetration between parallel panels had a strong effect on the productivity in parallel flat panels. This was in agreement with reports in the literature [88]. Although this approach is highly desirable for its low cost and many other benefits, it is also well known that CFD simulations need to be validated before use, and it is difficult to investigate all the decision variables of an experimental work.

The costs and energy consumption of the process are the key factors in the economics that inhibit the development of biofuels from microalgae. CFD simulations can reduce the cost and shorten the development cycle of photobioreactors. It can also be used to evaluate the energy consumption in the process, and can suggest combinations with other energy sources, such as wind energy and electrical energy (using the microalgae biomass), to form a complete and recyclable culture system. The mass cultivation of microalgae can absorb the $\mathrm{CO}_{2}$ in flue gases to reduce the release of greenhouse gas. It also utilize wastewater, which help to protect the environment and reduce the cost of biofuels from microalgae.

\section{Conclusions}

Biofuels can be obtained from a variety of sources, but microalgae is of particular interest as one of the most promising sources of biomass for biofuels. Biofuels from microalgae has been demonstrated to have broad application prospects, but these currently still remain at the exploratory stage. This review underlines several aspects involved in the mass cultivation of microalgae, including microalgae species, metabolic mechanism, culture conditions, and photobioreactors, to help the development of biofuels from microalgae. The following aspects need to be further developed. Microalgae species have to be screened to get good robustness for mass cultivation using a mature system. The metabolic mechanism of microalgae has to be regulated to increase the growth rate and lipid content of the microalgae under mass cultivation conditions with low costs, high efficiency and easy operation. The combination of mass cultivation and the use of flue gas or wastewater to reduce the costs has to be studied, and the metabolic mechanisms of $\mathrm{NO}_{x}$ and $\mathrm{SO}_{x}$ in microalgae need to be investigated. Photobioreactors, which affect the photosynthesis of microalgae for the initial conversion of sunlight into stored energy, should receive more attention, and special photobioreactors for the mass cultivation of micoalgae that overcome the problems of the costs and energy consumption are needed.

\section{References}

[1] Amaro H M, Guedes A C, Malcata F X. Appl Energ, 2011, 88: 3402

[2] Min E Z, Yao Zh L. Progr Chem (闵恩泽, 姚志龙. 化学进展), 2007, 19: 1050

[3] Apt K E, Behrens P W.J Phycol, 1999, 35: 215

[4] Rodolfi L, Zittelli G C, Bassi N, Padovani G, Biondi N, Bonini G, Tredici M R. Biotechnol Bioeng, 2008, 102: 100

[5] Brennan L, Owende P. Renew Sust Energ Rev, 2010, 14: 557

[6] Yang S, Chen Ch Y, Zhao Sh L, Niu Y H, Li L. Yunnan Chem Technol (杨苏, 陈朝银, 赵声兰, 牛耀辉, 李立. 云南化工), 2006, 33(3): 49 
[7] Wang J, Yang S L, Cong W, Cai Zh L. Chin J Proc Eng (王军, 杨素玲, 从威, 蔡昭玲. 过程工程学报), 2003, 3: 141

[8] de-Bashan L E, Antoun H, Bashan Y. FEMS Microbiol Ecol, 2005, 54: 197

[9] Wen J, Sun Y, Li B Sh, Zhu R X, Jiang Y J, Wen H Ch, Zhang Y K. Microbiol China (文锦, 孙远, 李宝硕, 朱瑞雪, 蒋云江, 温皓程, 张永 奎. 微生物通报), 2010, 37: 1721

[10] Perez-Garcia O, Escalante F M E, de-Bashan L E, Bashan Y. Water Res, 2011, 45: 11

[11] Chen G Q Jiang Y, Chen F. Food Chem, 2007, 104: 1580

[12] Song D H, Hou L J, Shi D J. Chin J Biotechnol (宋东辉, 侯李君, 施定 基. 生物工程学报), 2008, 24: 341

[13] Andersen R A, Kawachi M. Traditional Microalgae Isolation Techniques, In: Algal Culturing Techniques. Burlington: Elsevier Academic Press, 2005. Chapter 6, 83

[14] Li Y Q Horsman M, Wang B, Wu N, Lan C Q. Appl Microbiol Biotechnol, 2008, 81: 629

[15] Khozin-Goldberg I, Cohen Z. Phytochemistry, 2006, 67: 696

[16] Lynn S G, Kilham S S, Kreeger D A, Interlandi S J. J Phycol, 2000, 36: 510

[17] Rao A R, Dayananda C, Sarada R, Shamala T R, Ravishankar G A. Biorescource Technol, 2007, 98: 560

[18] Yao R, Cheng L H, Xu X H, Zhang L, Chen H L. Progr Chem (姚茹, 程 丽华, 徐新华, 张林, 陈欢林. 化学进展), 2010, 22: 1221

[19] Zhu Sh N, Wang Zh M, Shang Ch H, Zhou W Zh, Yang K, Yuan Zh H. Progr Chem (朱顺妮, 王忠铭, 尚常花, 周卫征, 杨康, 袁振宏. 化 学进展), 2011, 23: 2169

[20] Arabolaza A, Rodriguez E, Altabe S, Alvarez H, Gramajo H. Appl Environ Microbiol, 2008, 74: 2573

[21] Dahlqvist A, Stahl U, Lenman M, Banas A, Lee M, Sandager L, Ronne H, Stymne S. Proc Natl Acad Sci, 2000, 97: 6487

[22] Riekhof W R, Sears B B, Benning C. Eukaryot Cell, 2005, 4: 242

[23] National Algal Biofuels Technology Roadmap. U.S. Department of Energy, Energy Efficiency and Renewable Energy, 2010

[24] Rabbani S, Beyer P, Von Lintig J, Hugueney P, Kleinig H. Plant Physiol, 1998, 116: 1239

[25] Zhekisheva M, Boussiba S, Khozin-Goldberg I, Zarka A, Cohen Z. J Phycol, 2002, 38: 325

[26] Chen M, Tang H Y, Ma H Z, Holland T C, Ng K Y S, Salley S O. Bioresource Technol, 2011, 102: 1649

[27] Feng G D, Cheng L H, Xu X H, Zhang L, Chen H L. Progr Chem (冯国 栋, 程丽华, 徐新华, 张林, 陈欢林. 化学进展), 2012, 24: 1413

[28] Eriksen N T, Geest T, Iversen J J L. J Appl Phycol, 1996, 8: 345

[29] Cheng L H, Zhang L, Chen H L, Gao C. Sep Purif Technol, 2006, 50 : 324

[30] Chen G Q, Chen F. Biotechnol Lett, 2006, 28: 607

[31] Oyang Zh R, Wen X B, Geng Y H, Mei H, Hu H J, Zhang G Y, Li Y G. J Wuhan Bot Res (欧阳峥嵘, 温小斌, 耿亚红, 梅洪, 胡鸿钧, 张捷 艳, 李夜光. 武汉植物研究), 2010, 28: 49

[32] Liang Y, Mai K S, Sun Sh Ch, Yu D D. Mari Sci (梁英, 麦康森, 孙世 春, 于道德. 海洋科学), 2002, 26: 48

[33] Solovchenko A E, Khozin-Goldberg I, Didi-Cohen S, Cohen Z, Merzlyak M N.J Appl Phycol, 2008, 20: 245

[34] Roháček K, Barták M. Photosynthetica, 1999, 37: 339

[35] Hua R Ch (华汝成. 单细胞藻类的培养与利用. 北京: 中国农业出 版社). Beijing: China Agriculture Press, 1986

[36] Janssen M, Slenders P, Tramper J, Mur L R, Wijffels R. Enzyme Microb Tech, 2001, 29: 298

[37] Cong W, Su Zh F, Xue Sh Ch, Yang Ch Y (从威, 苏贞峰, 薛升长, 杨 成砚). CN Patent 101899385 A. 2010

[38] Cong W, Zhang Q H, Xue Sh Ch (从威, 张庆华, 薛升长). CN Patent 102260629 A. 2011
[39] Yin Z Q. Beijing: China Electric Power Press (殷志强. 中国可再生 能源发展战略研究从书-太阳能卷. 北京: 中国电力出版社), 2008

[40] Zhang Ch, Zou J Zh. Oceanol et Limnol Sin, 1997, 28: 599

[41] Li B, Ou L J, Lü S H. Mar Environ Sci, 2009, 28: 264

[42] Ding Y C, Gao Q, Liu J Y, Yi Y J, Liu J G, Lin W. Acta Ecol Sin (丁彦聪, 高群, 刘家尧, 衣艳君, 刘建国, 林伟. 生态学报), 2011, 31: 5307

[43] Wang L Zh, Wen H Ch, Zou Y, Zhou W W, Xie T H, Zhang Y K. Microbiology, 2010, 37: 336

[44] Yin C L, Liang Y, Zhang Q F. Fisheries Sci (尹翠玲, 梁英, 张秋丰. 水 产科学), 2008, 27: 27

[45] Kolber Z, Zehr J, Falkowski P. Plant Physiol, 1988, 88: 923

[46] Evans C T, Scragg A H, Ratledge C. Eur J Biochem, 1983, 132: 609

[47] Li Ying, Lü S H, Xu N, Xie L Ch. J Ecol Sci (李英, 吕颂辉, 徐宁, 谢隆 初. 生态科学), 2005, 24: 314

[48] Wen Sh Y, Zhao D Zh, Zhao L, Yang J H, Zhang F Sh, Wang L, Gao Sh G, Sun D. J Dalian Marit Univ (文世勇, 赵冬至, 赵玲, 杨建洪, 张丰 收, 王林, 高树刚, 孙东. 大连海事大学学报), 2009, 35: 118

[49] Wu Y, Sun J M, Sun P H, Zhang D M. J Fisheries Chin (吴垠, 孙建明, 孙培海, 张德明. 水产学报), 2004, 28: 742

[50] Wang G D, Zhang L L, Wu Y, Sun J M. J Hydroecol (王国栋, 张丽莉, 吴垠, 孙建明. 水生态学杂志), 2008, 1(2): 35

[51] Zhang Q D, Lu C M, Feng L J, Lin Sh Q, Kuang T Y, Bai K Zh. Chin Bull Bot (张其德, 卢从明, 冯丽洁, 林世青, 匡廷云, 白克智. 植物学 报), 1996, 38: 77

[52] Chiu S Y, Kao C Y, Huang T T, Lin C J, Ong S C, Chen C D, Chang J S, Lin C S. Bioresource Technol, 2011, 102: 9135

[53] Yang B, Chu Zh Sh, Jin X C, Yan F, Zeng Q R. Chin Environ Sci (杨波, 储昭升，金相灿，阎峰，曾清如. 中国环境科学), 2007, 27: 54

[54] Zhu M, Zhang X Ch, Mao Y X. Period Ocean Univ Chin (朱明, 张学成, 茅云翔. 中国海洋大学学报), 2005, 35: 499

[55] Liu J L, Zhang S L. Chin J Biotechnol (刘晶 张嗣良. 生物工程学报), 2000, 16(2): 119

[56] Wang Q, Qu Z M, Liu J L. Guangdong Agric Sci (王琴, 区子弁, 柳建 良. 广东农业科学), 2011: 180

[57] Sheehan J, Dunahay T, Benemann J, Roessler P, National Renewable Energy Lab., Golden, CO.: United States, 1998

[58] Ugwu C U, Ogbonna J C, Tanaka H. Process Biochem, 2005, 40: 3406

[59] Hsieh C H, Wu W T. Biochem Eng J, 2009, 46: 300

[60] Li X W, Li Y G, Shen G M, Yang D. Chin J Proc Eng (李兴武, 李元广, 沈国敏, 杨东. 过程工程学报), 2006, 6: 277

[61] Cong W, Liu M, Bao Y L (丛威, 刘明, 鲍亦璐). CN Patent 101948740A. 2011

[62] Chisti Y. Biotechnol Adv, 2007, 25: 294

[63] Scragg A H, Illman A M, Carden A, Shales S W. Biomass Bioenerg, 2002, 23: 67

[64] Travieso L, Hall D O, Rao K K, Benítez F, Sánchez E, Borja R. Int Biodeter Biodegr, 2001, 47: 151

[65] Hulatt C J, Thomas D N. Bioresource Technol, 2011, 102: 6687

[66] Hulatt C J, Thomas D N. Bioresource Technol, 2011, 102: 5775

[67] Yoon J H, Choi S S, Park T H. Bioresource Technol, 2012, 110: 430

[68] Jacob-Lopes E, Scoparo C H G, Lacerda L M C F, Franco T T. Chem Eng Process, 2009, 48: 306

[69] Rasoul-Amini S, Montazeri-Najafabady N, Mobasher M A, Hoseini-Alhashemi S, Ghasemi Y. Appl Energ, 2011, 88: 3354

[70] Feng P, Deng Z, Hu Z, Fan L. Bioresource Technol, 2011, 102: 10577

[71] Richmond A, Zhang C W. J Biotechnol, 2001, 85: 259

[72] Doucha J, Lívanský K.J Appl Phycol, 2009, 21: 111

[73] Zhan W, Sang M, Li A F, Zhang Ch W. Renew Energ Resour (展望, 桑 敏, 李爱芬, 张成武. 可再生能源), 2010, 28(3): 67

[74] Miu J L, Wang B, Kan G F, Ding Y, Jiang Y H, Hou X G, Li G Y. Mari Sci (缪锦来, 王波, 阙光锋, 丁燏, 姜英辉, 侯旭光, 李光友. 海洋科 学), 2005, 29: 2 


\title{
Graphical Abstract
}

Chin. J. Catal., 2013, 34: 80-100 doi: 10.1016/S1872-2067(11)60497-X

\section{Factors in mass cultivation of microalgae for biodiesel}

ZHU Junying, RONG Junfeng, ZONG Baoning*

SINOPEC Research Institute of Petroleum Processing

This review presents the factors that influence the mass cultivation of microalgae for biofuels, such as microalgae species/strains, metabolic mechanism, culture conditions and the photobioreactor.

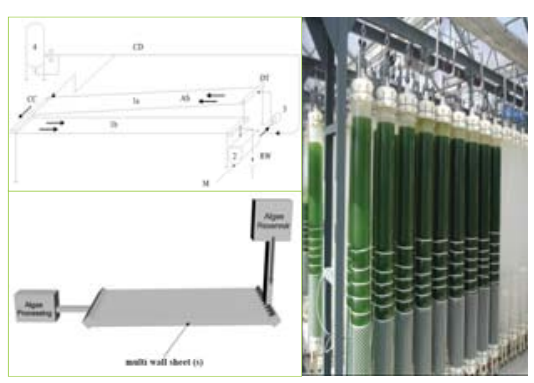

[75] Borowitzka M A.J Biotechnol, 1999, 70: 313

[76] Alías C B, López M C G M, Fernández F G A, Sevilla J M F, Sánchez J L G, Grima E M. Biotechnol Bioeng, 2004, 87: 723

[77] Chae S R, Hwang E J, Shin H S. Biores Technol, 2006, 97: 322

[78] Hu Q Guterman H, Richmond A. Biotechnol Bioeng, 1996, 51: 51

[79] Hu Q, Faiman D, Richmond A.J Ferment Bioeng, 1998, 85: 230

[80] Sierra E, Acién F G, Fernández J M, García J L, González C, Molina E. Chem Eng J, 2008, 138: 136

[81] Doucha J, Lívanský K. US Patent 5981 271. 1999

[82] Doucha J, Lívanský K. J Appl Phycol, 2006, 18: 811

[83] Rong J F, Huang X G, Zhou X H (荣峻峰, 黄绪耕, 周旭华). CN Patent 101870950 A. 2010

[84] Gorny R, Mason J P, Hilton G, Schwarz P. WO Patent 2011/034 567
A2. 2011

[85] Han Ch M, Yang J Q Chen H T, Zhang H, Liu M Sh (韩春梅, 杨建强, 陈红涛, 张涵, 刘敏胜). CN Patent 101735948 A. 2010

[86] Liu T Zh, Zhang W, Chen Y, Peng X W, Chen X L, Chen L (刘天中, 张 维, 陈昱, 彭小伟, 陈晓琳). CN Patent 102206570 A. 2010

[87] Sato T, Yamada D, Hirabayashi S. Energ Convers Manage, 2010, 51: 1196

[88] Slegers P M, Wijffels R H, van Straten G, van Boxtel A J B. Appl Energ, 2011, 88: 3342

[89] Qiu Ch T, Lin T, Zhang Q L, Xu H D, Chen Y Q, Gong M Ch. Chin J Catal (邱春天, 林涛, 张秋林, 徐海迪, 陈耀强, 龚茂初. 催化学 报), 2011, 32: 1227

\section{影响微藻规模化培养的因素}

\author{
朱俊英, 荣峻峰, 宗保宁* \\ 中国石油化工股份有限公司石油化工科学研究院, 北京 100083
}

摘要: 概述了微藻生物能源技术中的微藻规模化培养的研究现状, 从藻种篮选、代谢机理、培养条件和光生物反应器几个不同的 角度阐述了影响微藻规模化培养的因素, 为微藻生物能源的发展及光生物反应器的研发提供建议与思路.

关键词: 微藻; 生物能源; 光生物反应器; 油脂含量; 规模化培养

收稿日期: 2012-10-28. 接受日期: 2012-11-26. 出版日期: 2013-01-20.

*通讯联系人. 电话: (010)82368011; 电子信箱: zongbn.ripp@ sinopec.com

基金来源: 国家重点基础研究发展计划 (973 计划, 2012CB224803).

本文的英文电子版由Elsevier出版社在ScienceDirect上出版(http://www.sciencedirect.com/science/journal/18722067).

\section{1. 前言}

能源是社会发展和经济增长的基本驱动力,其需求 量日益增加, 而化石能源作为一种不可再生资源, 面临着 巨大的供给压力. 因此, 寻求替代能源变得尤为重要. 生 物能源作为可再生绿色能源备受关注 ${ }^{[1,2]}$. 第一代生物能 源是以淀粉、玉米等粮食作为原材料提取生物燃料; 纤 维素生物能源是以农作物秙秆等作为原材料提取生物 燃料, 即第二代生物能源; 微藻生物能源, 是通过培养微 藻提取生物燃料, 被称为第三代生物能源, 与前两代生物
能源相比, 它具有独特的优势而得到广泛研究 ${ }^{[3-5]}$.

微藻生物能源技术主要涉及四个领域: 藻种笁选、 微藻规模化培养、微藻采收和微藻生物质加工处理. 这 是将生物工程与过程工程相结合的一个新领域, 需要进 行大量的研究及实践论证. 微藻生物能源技术所涉及的 各个环节中, “规模化培养” 是瓶颈, 大规模地获得高油脂 含量的微藻生物质是微藻生物能源技术能否产业化的 最关键的难题. 很多微藻具有较高的油脂含量, 通过篮 选, 已经得到多株高油脂含量的藻种, 主要为绿藻和硅 藻, 例如小球藻 (Chlorella), 栅藻 (Scenedesmus), 褐指藻 
(Phaeodactylum). 但是, 这些藻种在规模化培养中的油脂 含量和生长速率显著低于在实验室培养的. 这可能是由 于在实验室时, 为微藻提供了最适环境条件, 使其处于最 佳生长状态.而在规模化培养中, 培养条件未能达到最佳 生长条件, 影响了油脂含量和生长速率. 在规模化培养 中, 如何实现微藻快速生长而又不影响油脂含量成为阻 碍微藻生物能源发展的瓶颈. 因此, 需要综合考虑藻种 选育、代谢机理、培养条件、光生物反应器等多方面因 素, 才能研发出适合微藻规模化培养的成套技术, 推动微 藻生物能源的发展.

\section{2. 藻种}

\section{1. 微藻}

微藻是一类在显微镜下观察到的、具有光合作用 的、自由生活的有机体, 其大小为几微米, 如小球藻约为 $3 \sim 5 \mu \mathrm{m}$, 它们广泛存在于水生态系统中, 如淡水、盐水 $(<3.5 \%$ 盐度)、海水 $(3.5 \%$ 盐度) 和在一定温度、 $\mathrm{pH}$ 范围 内的水环境. 微藻属于藻类, 藻类还包括巨型藻 (或海 藻), 其细胞组织已经分化成类似于高等植物的根、叶、 颈, 有的长达 $60 \mathrm{~m}$. 微藻又可分为原核微藻和真核微藻. 原核微藻以蓝藻 (Cyanobacteria) 为主, 又名蓝细菌 $(C y$ anobacteria)、蓝绿藻 (blue-green algae), 属于传统的藻类 学范畴, 含叶绿素 $\mathrm{a}$, 不形成细胞器, 能进行光合作用, 细 胞中蛋白质含量高, 可达干重的 70\%, 脂肪含量低, $5 \%$ 左 右 $^{[6]}$. 真核微藻种类比较多, 例如绿藻 (Chlorophyta)、硅 藻 (Bacillariophyta)、黄藻 (Xanthophyta), 细胞中蛋白质 和脂肪的含量较高, 是生物能源藻种的主要来源.

微藻作为生物能源的原料具有独特的优势: 它生长 快、油脂含量高 $(20 \%$ 50\%) ; 其培养不需消耗陆地农耕 产品和占用耕地; 可以在污水及盐水中生长, 不需占用 生活用水及灌溉用水; 可以利用废气中的 $\mathrm{CO}_{2}$ 进行光合 作用; 可以用来生产多种燃料, 其副产品价值也很高. 除 此之外, 光合作用的生理机制与植物相似, 但与陆生植物 相比, 由于其构造简单而具有突出的光能转化效率, 不需 要维持和复制各种组织结构, 藻细胞可以将其获得的大 部分能量转化为生物量. 然而, 微藻的优势不仅仅因为 具有高效的光合效率成为生物能源的主要研究对象, 更 重要的是, 它不像陆生植物需要生产特殊的油类来养育 种子, 每个微藻细胞就像一个油脂制造厂, 尽其可能地将 获得的能量转化为油脂.

微藻能够进行多种营养模式也是非常具有吸引力 的特性 ${ }^{[7 \sim 10]}$, 它们既可利用光能和无机盐进行光能自养 (autotroph), 又可利用有机物进行异养 (heterotroph), 还可 同时进行这两种营养方式, 即兼养 (mixotroph). 部分微 藻, 例如小球藻, 可以利用现成的有机物进行异养或兼 养, 这样生长更快. 微藻营养方式的多样性既可将微藻 培养与 $\mathrm{CO}_{2}$ 减排相结合, 又可利用污水培养微藻, 因此微 藻是非常具有潜力的生物能源研究对象. 异养或兼养的 生长特性是微藻非常突出的特点, 因而在有光和无光的 条件都能生长, 可以通过添加碳源的方法缩短微藻的培 养周期, 并促进油脂的积累. 添加碳源, 尤其是有机碳源, 一个非常不利的潜在因素是可能促进了某些微生物的 生长, 增加了微藻受污染的几率.

微藻中可以利用的资源有燃料和副产品两大种 类 ${ }^{[5,11,12]}$. 可能的燃料类型包括油脂、氢、类异戊二烯、 碳水化合物、酒精 (直接或生物量转化) 和甲烷 (厌氧发 酵). 油脂具有较高的能量和开发潜力, 主要以甘油三酯 (TAGs) 的形式存在, 常分布在细胞膜及胞内细胞器膜 上, 部分油脂中含有碳水分子, 使其与石油有相似之处. 除了油脂外, 微藻副产品的价值也很高, 包括蛋白质、色 素, 可用于医药品、食品、保健品、特殊的动物饲料、 纳米材料等. 微藻在用于生产燃料和副产品的问题上存 在较大争议, 我们认为, 这不应该是固定的模式, 应根据 藻种的生理生化特性, 将细胞内代谢物与产品相结合, 再 根据培养条件选择合适的模式体系, 进行过程优化, 从而 就可能将单一特性与最终产品相匹配, 而非单纯的将策 略集中于燃料产品或非燃料产品.

\section{2. 微藻的䇻选鉴定}

藻种对于微藻生物能源产业来说至关重要, 它们的 特性直接影响着后继的规模化培养、采收和生物质加工 处理. 目前, 能源微藻的藻种包括绿藻、硅藻、金藻和裸 藻等, 其中绿藻的研究和应用较为广泛. 多种微藻可以 从藻种库中获得, UTEX(The Culture Collection of Algae at the University of Texas at Austin, Texas)有约3000种, CCMP(The Provasoli-Guillard National Center for Culture of Marine Phytoplankton at the Bigelow Laboratory for Ocean Sciences in West Boothbay Harbor, Maine) 有 2500 多种. 然而, 由于部分藻种在藻种库中保存的时间比较 久, 有的甚至有几十年, 藻种原有的一些特性可能已经丢 失, 例如繁殖能力、营养多样性. 为了得到功能齐全、生 命力旺盛的藻种进行微藻生物能源的开发, 需要从环境 中分离新的、本土的藻种, 通过分离、篮选和鉴定保存 具有潜力的藻种. 根据新分离的藻种可以获得地域环境 的变化对微藻生理指标影响的基础数据, 为后期的规模 
化培养提供参考依据 ${ }^{[13]}$. 为了尽可能最大限度地获得多 种多样的新陈代谢功能, 藻种需要从一个涵盖足够大 的、多样性的环境中采集, 例如淡水、盐水、海洋和盐 度超高的环境以及土壤, 甚至是与其它生物体共存的环 境. 新藻种的采样和分离过程中, 应详细记录采集时间、 地点、环境因素和培养条件, 还应说明微藻在自然环境 中的演替. 并不是所有的藻种都适合规模化的人工培养, 我们在实践中发现很多高油脂含量的藻种在规模化培 养中会出现各种问题. 中国石化与中国科学院合作, 在 全国范围内采集、分离油脂高、生长速率快的藻种, 采 集的范围包括自然海域、内陆淡水区域、沿海地区和荒 漠地区等, 已分离得到多株符合要求的藻种, 并对其中具 有开发潜力的藻种进行基因测序, 通过基因工程的手段 进行改良, 为微藻生物能源产业化提供优质藻种.

藻种的笁选主要包括生理、代谢产物和生命力. 藻 种生理指标包括一系列参数, 例如最大生长速率、最大 细胞密度、环境因素变化的耐受力 (温度、 $\mathrm{pH}$ 、盐度、 溶氧及 $\mathrm{CO}_{2}$ 水平等), 及野外与实验室操作的可变性. 藻 种代谢产物的篮选不仅包括代谢成分和含量, 还包括这 些代谢产物作为生物能源的潜力, 需要测定细胞内油 脂、蛋白质和碳水化合物的组成并对其经济性进行评估, 其中藻种油脂的快速分析可以大大简化工作, 理想的分 析方法应该可以区别中性和极性油脂, 并能提供脂肪酸 的结构. 很多藻种可将代谢产物分泌到培养基中, 这部 分代谢产物常常被忽略. 研究表明, 它们具有较高的价 值. 因此, 藻种耖选时应对细胞外分泌物进行分离鉴定. 此外, 还应考虑藻种的生命力, 包括培养密度、适应性、 稳定性及特定环境中对掠食者的敏感性等等. 研究表明, 微藻在实验室与规模化培养中存在差异, 为了确定藻种 的生命力, 小试模拟微藻规模化培养是必需的, 因此需要 通过小试模拟规模化培养进一步篎选适宜的藻种. 在中 国石化与中国科学院合作的“微藻生物柴油成套技术的 研发”项目中, 通过建立完善的实验室藻种评价体系, 从 自然界获得的藻种中高效篮选出生长速率快、油脂含量 高的藻种, 尤其是一些高耐受性的藻种, 然后通过实验室 小规模扩大培养进一步确定藻种的生长活力和耐受性, 最后通过 $100 \mathrm{~L}$ 级以上的规模化培养确定微藻生物能源 产业的藻种.

\section{3. 油脂的合成和调控}

甘油三酯 (TAGs) 是中性油脂的主要组成部分, 也是 微藻生物能源的主要来源, 它是多种微藻在胁迫环境下 的主要储存物质, 例如高光、营养缺失 ${ }^{[14 ~ 17]}$. 某些微藻在
自然条件下也可以在体内积累大量的 TAGs(占干重的 $30 \%$ 60\%), 在光合效率和产油脂的潜能上比陆生植物 要高很多. 然而, 在生理生化和分子生物学水平上, 关于 调控微藻脂肪酸和 TAGs 合成的研究较少.

TAGs 合成的主要途径 (Kennedy Pathway) 为在基质 中合成脂肪酸, 将脂肪酸转化为甘油骨架, 最后通过三步 连续的乙酰辅酶 A 转酰基作用, 在内质网上形成 TAGs. 乙酰辅酶 $\mathrm{A}$ 羧化酶 (ACCase) 催化乙酰辅酶 $\mathrm{A}$ 转化为丙 二酰辅酶 $\mathrm{A}$ 是脂肪酸生物合成的第一步, 也是限速的一 个关键代谢步骤. 因此, 有些学者认为, 提高 ACCase 的 活性有利于提高微藻细胞内的油脂含量, 然而实验结果 却并非如此. 通过转基因的方法使微藻细胞内的 ACCase 活性大大提高, 但油脂积累并没有显著增加, 可能 的原因是虽然 ACCase 是油脂合成中的关键酶, 但仍需 要多步反应才能合成 TAGs, 在后续的多步反应中该酶 活性逐渐被消耗, 并不利于 TAGs 的积累 ${ }^{[18,19]}$. 微藻中可 能存在多种TAGs 合成途径, 而且各个途径对于 TAGs 合 成的贡献依赖于环境或培养条件. 在植物和酵母中发现 了另一种将膜脂或/和碳水化合物转化为 TAGs 的方式, 这种方式不依靠酰基辅酶 $\mathrm{A}^{[20,21]}$; 还未在微藻中发现这 种转化方式. 脂肪酸通常是膜脂和 TAGs 的合成前体, 微 藻细胞中这些前体在这两种途径中是如何分配的、这两 种类型的油脂是如何相互转化的以及这个过程中基因 是如何调控的都需要深入研究. 如果微藻中油脂/TAGs 的含量可以表现为种类或同类的特异性, 不同藻种甚至 同株藻种在某一环境中表现出特定的油脂/TAGs 含量, 那么就很难将由实验室藻种得到的油脂合成的调控机 理推广到规模化培养中 ${ }^{[22]}$. 类似地, 将植物中油脂生物 合成的调控信息用于藻种改良也存在一定困难. 因此, 研究脂肪酸和油脂合成的关键基因/酶和合成途径对微 藻生物能源产业很重要, 还需研究它们在微藻新陈代谢 中的作用, 以及培养环境的变化对基因/酶表达的影响, 阐明规模化培养中油脂合成的调控机理.

在环境胁迫下, 例如氮、磷、硅营养胁迫, 以及盐度、 温度和光强胁迫 ${ }^{[14 ~ 17]}$, 藻细胞迅速停止分裂, 并且积累 TAGs 作为主要的能量储存物质. TAGs 的合成、积累、 沉淀并形成细胞质油脂体是微藻在环境胁迫下默认的 合成途径. 在胁迫条件下 TAGs 的合成途径可能更多样 化. 例如, 胁迫条件下, 光合作用电子传递链中积累的过 剩电子可能诱导活性氧大量产生, 这些活性氧反过来抑 制光合作用和破坏膜脂、蛋白质和其它大分子, 此时合 成的 TAGs 可以消耗过剩的电子而缓解光氧化的胁迫. 
C18 脂肪酸的合成需要消耗约 24 个由电子传递链生成 的 NADPH, 几乎是合成同样量的碳水化合物和蛋白质 所需能量的两倍. 因此, 在高光或其它胁迫下, 合成 TAGs 可以起到释放过量电子保护光合作用电子传递链 活性的作用 ${ }^{[23]}$. 在微藻中, TAGs 的合成途径往往伴随着 二级类胡萝卜素的合成 ${ }^{[24,25]}$. 类胡夢卜素合成途径中产 生的分子 (如 $\beta$-胡夢卜素, 叶黄素) 被运输到细胞内脂质 体, 这些脂质体分散在外围可以作为遮光剂, 减少过剩的 光照对叶绿体活性的影响. TAGs 的合成可能还需要卵 磷脂、半乳糖酯或从膜系统中排泄的有毒脂肪酸, 如酰 基供体, 因此具有膜脂解毒并以 TAGs 的形式将其沉淀 的作用. 培养液中氮浓度是影响微藻油脂含量的一个重 要因素, 当氮浓度较低时, 藻细胞内的蛋白质减少, 脂肪 和碳水化合物增加; 伴随着 TAGs 的积累, 而且这种积累 会随着氮的减少或受限而加速. Dunaliella tertiolecta 在 正常和缺氮培养基中培养时, 第五天出现了明显的油脂 积累, 而且在正常培养基中的积累量大. 然而, 在缺氮的 培养条件下单位藻细胞密度的油脂积累更快, 第三天就 出现了明显的积累,在第四天时达到最大, 是正常培养基 中藻细胞的 5 倍. 虽然在两种培养条件下藻细胞油脂积 累的速率不同,但脂肪酸的组成几乎没有差别 ${ }^{[26]}$.

目前, 部分微藻的全基因组信息已经或很快可以得 到, 在不同培养条件下, 产油微藻的 EST(Expressed Sequence Tag)序列可以提供不同培养条件下微藻的基因 表达以及与 $\mathrm{cDNA}$ 微阵列和/或蛋白质组的信息, 这些都 将为调控微藻光合作用碳分配和油脂合成提供理论基 础. 基于这些信息, 在微藻生物能源产业化过程中, 通过 基因工程改良藻种新陈代谢是一条非常有效的途径, 可 行的方法包括随机的、特异的突变和基因转化, 增强微 藻各方面的生理指标. 利用基因工程的方法对微藻油脂 代谢进行调控有利于提高油脂含量、降低微藻生物能源 成本, 例如增强脂肪酸合成途径、调控 TAGs 合成的旁路 途径、抑制脂肪酸合成的竞争途径以及抑制脂肪酸分解 等. 除此之外, 还可改变油脂的组成, 提高产品及副产品 价值 ${ }^{[18,19,27]}$. 值得注意的是, 如果在微藻规模化培养中选 择转基因藻种, 要对其生态安全性进行评估, 防止造成生 态入侵.

\section{3. 影响微藻生长和油脂含量的因素}

微藻是非常具有研发潜质的一类生物原料. 首先, 它具有基因序列和基因改造功能,适合细胞过程的研究, 可以得到关于细胞代谢过程和燃料前体合成调控的信
息,为后期培养提供有力依据; 其次,微藻适应范围广, 可 以在不同环境下培养. 然而, 大量研究表明, 并不是所有 在实验室中生长良好的藻种都适合规模化培养. 对于一 些已熟知的物种, 将实验室模式中得到的经验应用于规 模化培养中比较容易; 对于微藻而言, 却并不确定, 也就 是说, 并不能简单地将实验室微藻的培养经验完全应用 于规模化培养. 在实验室条件下研究影响微藻生长的因 素, 并结合实际规模化培养中出现的问题具体分析, 对微 藻规模化培养非常重要. 影响微藻生长的因素很多, 主 要有光、营养盐、 $\mathrm{CO}_{2} 、 \mathrm{pH}$ 、温度和 $\mathrm{O}_{2}$ 、以及其它胁迫 因素等 ${ }^{[28 \sim 31]}$. 微藻的生长及脂类物质的含量与光照、氮、 磷和温度等培养条件密切相关 ${ }^{[15,32,33]}$. 不同微藻生长和 积累油脂的培养条件不尽相同,应该根据不同藻种确定 最佳培养条件, 提高生长速率和油脂含量. 在藻种确定 的条件下, 培养条件是影响微藻油脂含量的决定因素, 也 是规模化产油微藻培养的主要工艺控制因素, 在本领域 有大量专利文献报道.

\section{1. 光}

光的三因素, 光强、光质和光周期都会影响微藻的 光合效率 ${ }^{[34]}$. 光强, 即光的强度, 它在光补偿点以上才会 有生物量的积累, 当光强超过光饱和点后, 即使光强再增 加, 光合效率也不会增加, 而且光强过高对光合效率还有 抑制作用, 因此在培养过程中应使光强处于这两个转折 点之间, 并且尽量接近光饱和点使微藻处于最大光合效 率的状态. 光质, 指光的波长, 微藻和植物的光合系统中 有两个系统, 即光系统 I 和光系统 II. 光系统 I 的吸收峰 位于 $680 \mathrm{~nm}$, 光系统 II 的吸收峰位于 $700 \mathrm{~nm}$, 微藻和植物 对不同波长光的吸收量是不一样的. 例如, 小球藻对红 光的利用率最大, 其次为黄光和青光 ${ }^{[35]}$. 光周期, 即光暗 交替, 对光合作用效率也有影响. 研究表明, 藻细胞在光 区与暗区交替达到一定频率 (常高于 $1 \mathrm{~Hz}$ ) 时, 就会产生 “闪光效应”, 从而有利于提高微藻对光的利用率 ${ }^{[36]}$. 利 用这个现象对光生物反应器进行改良,在板式等封闭式 光生物反应器内壁上加入一些挡板, 可以提高微藻的生 产率 ${ }^{[37,38]}$. 许多光生物反应器的创新都在于如何高效地 利用闪光效应. 在微藻规模化培养中, 常以自然光作为 光源, 其优点首先是可以降低成本, 而且我国太阳能资源 丰富, 年总辐照量可到达 $280 \mathrm{~W} / \mathrm{m}^{2}$ 以上, 大部地区可达 到 $120 \mathrm{~W} / \mathrm{m}^{2[39]}$; 微藻对自然光的利用率可达到总辐照量 的 3\% 11\%, 如果再加上人工条件, 利用率则更高. 其次, 自然光光质好, 全波长. 自然光的缺点就是光强难控制, 中午光强大, 微藻易发生光抑制, 阴雨天光照不足, 影响 
微藻生长.

\section{2. 营养盐}

营养盐是微藻生长的基础, 微藻生长必需的元素有 碳、氧、氢、氮、钾、钙、镁、铁、硫、磷等十几种, 此 外还需要一些微量元素. 碳、氢、氧、氮、磷和钾是微 藻生长所需的大量元素, 前三种可以从水和空气中获得, 后三种需从营养盐中得到. 在培养过程中氮磷往往会成 为限制因素, 影响藻细胞的生长和细胞内组分的合成, 氮 /磷比常作为微藻氮磷受限制的重要指标, 该比值过高表 示磷受限制, 比值过低表示氮受限制.

氮是微藻生长、发育、繁殖等生理活动不可缺少的 重要元素之一, 不同的氮源及浓度对油脂的积累也有重 要的影响. 通常可以被微藻利用的氮源有铵盐、硝酸盐 及尿素等, 但在吸收速度与利用程度上有所差异 ${ }^{[40]}$. 研 究表明, 微藻利用氮的能力的顺序为: 氨氮 $>$ 尿素 $>$ 硝态 氮 > 亚硝态氮, 这是因为氨氮可以直接通过转氨基作用 合成氨基酸,而其余氮源都需要通过酶的催化转为氨氮 再被细胞利用. 但是很多研究表明, 利用尿素和硝酸盐 培养微藻也可以达到非常好的效果 ${ }^{[41,42]}$. 在研究尿素、 硝酸钠和碳酸氢铵对小球藻生长及油脂含量的影响时 发现, 尿素对生长的促进作用最大, 而硝酸钠对油脂的积 累最有利, 综合考虑生物量产率和油脂含量, 宜选择硝酸 钠作为优化氮源, 但成本较高 ${ }^{[43]}$. 随着氮浓度的增加, 微 藻的生长速率表现出先升高后下降的现象, 高浓度的氮 对生长有一定抑制作用 ${ }^{[43,44]}$. 这可能是由于高浓度氮源 促进微藻的大量繁殖, 磷逐渐被耗尽, 氮/磷比例失调, 而 藻细胞吸收过量的氮源, 不利于细胞的分裂 ${ }^{[45]}$. 在不同 浓度的有机氮和无机氮培养基中培养 Dunaliella tertiolecta, 藻细胞在 $23 \mathrm{mmol} / \mathrm{L}$ 的 $\mathrm{NaNO}_{3}$ 中生长速率最高, 当 $\mathrm{NaNO}_{3}$ 浓度增加到 $46 \mathrm{mmol} / \mathrm{L}$ 时, 藻细胞的生长速率并 没有增加; 分别在 $1 \mathrm{mmol} / \mathrm{L}$ 的 $\mathrm{NH}_{4} \mathrm{Cl}$ 与 $2.3 \mathrm{mmol} / \mathrm{L}$ 的 $\mathrm{NaNO}_{3}$ 中培养时藻的生长速率相当, 当增加 $\mathrm{NH}_{4} \mathrm{Cl}$ 的浓 度时生长速率有所降低. 该研究结果表明, 虽然藻细胞 需要将 $\mathrm{NO}_{3}{ }^{-}$还原为 $\mathrm{NH}_{4}{ }^{+}$, 但过高的 $\mathrm{NH}_{4}{ }^{+}$不利于细胞的 生长. 这可能是由于过高浓度的 $\mathrm{NH}_{4}{ }^{+}$影响了藻细胞的呼 吸作用 ${ }^{[26]}$.

低氮浓度有利于微藻油脂的积累, 这也成为目前规 模化培养中提高微藻油脂含量的常用工艺. 可能是由于 当氮含量较低时, 细胞内的腺苷一磷酸 (AMP) 脱氨酶的 含量增加, 它将 AMP 大量转化为肌苷一磷酸 (IMP) 和氨, 而线粒体中异柠檬酸脱氢酶 (ICDH) 多为 AMP 依赖性脱 氢酶, 细胞内 AMP 浓度的降低将减弱甚至完全抑制该酶
的活性 ${ }^{[46]}$. 藻细胞内的柠檬酸可被柠檬酸裂解酶催化生 成乙酰辅酶 $\mathrm{A}$, 也可进入柠檬酸循环, ICDH 是柠檬酸循 环中的催化酶, 在氮浓度含量较低时, ICDH 活性的降低 促使柠檬酸更多的被催化生成乙酰辅酶 $\mathrm{A}$, 从而使细胞 内脂肪的积累量增加.

磷是藻类生长发育所必需的元素. 常用的磷源有磷 酸盐、磷酸氢盐. 磷在藻细胞代谢过程以及在水生态系 统中都起着重要作用, 参与信号传递、能量转换和光合 作用等生理活动, 也是水体中浮游植物竞争产生优势种 群的原因之一. 微藻对不同形态的磷酸盐有着不同的代 谢机理, 其中正磷酸盐最容易被吸收, 且对生长促进作 用显著 ${ }^{[47]}$. 在一定范围内, 微藻的生长随着磷浓度的增 加而提高, 当磷浓度过高时, 不但不会促进微藻的生长, 反而对微藻的生长起抑制作用. 这可能是由于过高的磷 改变了氮/磷比, 从而抑制了细胞分裂 ${ }^{[48]}$.

\section{3. $\mathrm{CO}_{2}$ 和 $\mathrm{pH}$}

$\mathrm{CO}_{2}$ 是微藻和植物光合作用的底物, 又是光合作用 的限制因子之一. 微藻进行光合作用需要一定浓度的 $\mathrm{CO}_{2}$, 其体积比例为 1\% 5\% 时可达到最大光合效率; 空 气中的含量虽然较低, 但通过鼓气也可以达到较高的光 合效率. $\mathrm{CO}_{2}$ 浓度的提高能显著地提高微藻对数生长期 的光合效率和光合作用饱和光强, 这与 $\mathrm{CO}_{2}$ 浓度的提高 能得到较高的微藻生物量相一致 ${ }^{[49]}$. 微藻培养过程中可 适量添加 $\mathrm{NaHCO}_{3}$, 以缓解 $\mathrm{CO}_{2}$ 供应不足, 作为碳源促进 藻细胞生物量的增加; 同时还可起到缓冲剂的作用. 但 是, 一次性添加 $\mathrm{NaHCO}_{3}$ 浓度不宜过高, 否则藻液 $\mathrm{pH}$ 偏 碱性, 微藻生长就会受到限制 ${ }^{[43]}$. 补充 $\mathrm{CO}_{2}$ 有利于新月 菱形藻对光能的利用和转化, 提高光合效率, 为光合作用 碳循环提供充足的能量, 进而促进新月菱形藻代谢产物 积累 ${ }^{[50]} . \mathrm{CO}_{2}$ 浓度升高可能在两个方面影响新月菱形藻 的光合作用: (1) 增加了 $\mathrm{CO}_{2}$ 对 Rubisco (Ribulose bisphosphate carboxylase oxygenase) 结合位点的竞争, 从 而提高羧化速度; (2) 通过抑制光呼吸作用提高净光合 效率 ${ }^{[49,50]}$. 另外, 增加 $\mathrm{CO}_{2}$ 浓度有利于微藻光系统 II 光化 学效率的提高, 把捕获的光能以更高的效率转化为化学 能, 为光合作用碳同化提供充足的能量 ${ }^{[51]}$. 这可能也是 补充 $\mathrm{CO}_{2}$ 有利于提高光合效率的原因之一. 工业烟道气 中 $\mathrm{CO}_{2}$ 的含量较高, 完全能满足微藻对 $\mathrm{CO}_{2}$ 的需要, 若能 将其应用到微藻规模化培养中, 既降低了微藻培养成本 又可用于减排 $\mathrm{CO}_{2}$, 非常具有意义. 研究表明, 微藻是能 利用烟道气生长的, 用不同浓度的 $\mathrm{CO}_{2}(2 \%, 10 \%$ 和 $25 \%)$ 气体和烟道气 $\left(25 \% \mathrm{CO}_{2}, 4 \% \mathrm{O}_{2}, 0.008 \% \mathrm{NO}\right.$ 和 $0.008 \%$ 
$\mathrm{SO}_{2}$ ) 培养野生型和突变型小球藻, 结果表明, 通入 $2 \%$ $\mathrm{CO}_{2}$ 时小球藻的生长最快, 而且突变型比野生型小球藻 生长速率要高 ${ }^{[52]}$. 该研究还发现, 通入烟道气时, 两株小 球藻生长比通入不同浓度的 $\mathrm{CO}_{2}$ 时生长速率高. 这可能 是由于烟道气不仅提供了碳源, 还提供了氮源. 中国石 化在石家庄建成了 $400 \mathrm{~m}^{2}$ 的微藻培养基地, 是国内首套 利用微藻直接减排炼油厂烟气中 $\mathrm{CO}_{2}$ 的示范装置. 在此 基地中, 小球藻的小试培养已取得成功, 为下一步 $\mathrm{CO}_{2}$ 减 排奠定了基础.

$\mathrm{pH}$ 是影响水环境中无机碳 (DIC) 各形式丰度的一 个重要因素. 在 $\mathrm{pH}=5$ 以下, $\mathrm{DIC}$ 大部分为 $\mathrm{CO}_{2} ; \mathrm{pH}=6.6$ 时, $\mathrm{CO}_{2}$ 与 $\mathrm{HCO}_{3}{ }^{-}$基本持平; 当 $\mathrm{pH}=8.3$ 时, $\mathrm{DIC}$ 绝大部分 为 $\mathrm{HCO}_{3}{ }^{-[53]}$. 因此在微藻培养过程中应控制 $\mathrm{pH}$, 便于 $\mathrm{CO}_{2}$ 的吸收利用. $\mathrm{pH}$ 还能直接影响微藻细胞膜的渗透性 及无机盐的离子形态, 间接影响细胞对无机盐的吸收. 研究表明, 小球藻在高光照、高 $\mathrm{pH}$ 时, 藻细胞对磷酸盐的 吸收增加; 而在低光照、低 $\mathrm{pH}$ 时, 藻细胞对磷酸盐的吸 收量减少. 随着光合作用的进行, 培养液中的 $\mathrm{CO}_{2}$ 不断被 消耗掉, 使得培养液的 $\mathrm{pH}$ 不断上升, 甚至超出微藻所能 耐受的范围, 成为微藻生长的限制因子, 此时需要添加一 些酸类物质来调节 $\mathrm{pH}$, 如盐酸和乙酸. 比较而言, 乙酸具 有很大的优势, 既可调节微藻培养液的 $\mathrm{pH}$ 值, 也可以作 为碳源被微藻利用, 因此对微藻的生长具有双重作用 ${ }^{[54]}$.

\section{4. 其它因素}

其它因素, 如温度、 $\mathrm{O}_{2}$, 都会影响微藻的生长. 不同的 藻种对温度的适应范围不同, 淡水藻 (例如小球藻、栅藻) 能适应的温度范围为 $5 \sim 35^{\circ} \mathrm{C}$, 最适温度为 $25 \sim 30^{\circ} \mathrm{C}$, 在 培养过程中应尽量使其处于最适温度范围内. 温度有时 也会成为提高微藻油脂含量的胁迫因素. $\mathrm{O}_{2}$ 是微藻呼吸 作用必需的气体, 也是光合作用释放的气体, 它对微藻细 胞而言是非常重要的. 微藻在进行旺盛的光合作用时会 在培养液里积累大量的溶氧, 如果这些溶氧不能及时排 放就会形成高溶氧, 会对微藻的生长甚至生存形成严重 的胁迫, 因此在规模化培养中要注意溶氧的释放. 溶氧 对微藻的影响主要有两方面: (1) 可能会氧化碳同化过程 中的一种或数种酶及电子传递链供体受体, 对微藻形成 胁迫; (2) 光合作用是产氧的过程, 过多的溶氧会促使光 合反应朝逆向进行, 对光合作用产生抑制作用。

\section{4. 微藻光生物反应器}

微藻光生物反应器是微藻规模化培养过程中的关 键设备, 也是目前微藻规模化培养的技术瓶颈之一, 研发
适合的微藻光生物反应器是推动微藻规模化培养技术 发展的首要任务. 微藻光生物反应器的设计需考虑多方 面的因素, 以达到传光、传质、传动效率的提高和降低 成本的目的. (1) 光是限制微藻规模化培养的主要因素. 从经济角度出发, 微藻规模化培养常使用自然光, 因此微 藻光生物反应器应具有高的表面积/体积比, 增加透光率 及微藻对光的利用效率. (2) $\mathrm{CO}_{2}$ 是微藻生长的重要物 质, 在微藻规模化培养中消耗量大, 需通过合理的设计提 高 $\mathrm{CO}_{2}$ 的传质效果和利用率. (3) 溶氧的积累不利于微藻 的生长和光合作用的进行, 在封闭式反应器表现的比较 突出, 在一定程度上限制了封闭式反应器的大小和规模. (4) 在开放式反应器中水分蒸发比较严重, 尤其是在水资 源不丰富的地区, 而封闭式反应器水分蒸发相对较少, 因 此需要根据微藻规模化培养地点的自然条件选择合适 的反应器和培养模式, 尽量降低水的消耗; 开放式光生 物反应器由于水分的蒸发, 温度比较容易控制, 但是对于 封闭或半封闭式光生物反应器, 温度控制是关键技术, 在 某些特殊地区及不同季节应有相应的控温措施. (5)微藻 光生物反应器设计时还需考虑 $\mathrm{pH}$ 、营养盐的添加以及 清洗等问题, 在有外加驱动力的情况下还应考虑剪切力 对微藻的伤害. 总之, 对于光生物反应器的研发设计, 如 合提高“表面积/体积比”和“降低动力成本”是最主要的 考虑因素.

微藻光生物反应器按其培养模式可以分为开放式 和封闭式. 表 1 对两种培养模式进行了比较. 可见, 两种 培养模式各有利弊, 只有充分了解两种培养模式下光生 物反应器的优缺点, 才能对其进行改良和创新, 研发出适 合微藻规模化培养的光生物反应器. 在实践中, 目前无 论是哪种模式, 规模化培养过程中的“能耗“都相当可观, 是主要成本因素之一, 也是未来光生物反应器创新中必 须解决的核心问题.下面介绍几种具有代表性的微藻光 生物反应器.

\section{1. 开放式光生物反应器}

跑道池是典型的开放式光生物反应器, 应用也很广 泛. 跑道池在实际中一般设计面积较大, 单独或几个联 合形成一个整体, 藻液厚 $15 \sim 30 \mathrm{~cm}$, 常以叶轮转动的方式 推动藻液在池内循环、混合, 防止藻细胞沉淀吸附并增 加微藻与光的接触概率. 为增加藻液的流动, 许多学者 进行了多方面尝试, 诸如用拖动档板、连续流动槽、气 升、液体喷射等多种手段. 20世纪60 70年代,美国、以 色列等国家将跑道池应用于工业污水处理; 80 90 年代 起, 中国、美国、日本等将其应用于生产保健品, 例如螺 
旋藻 ${ }^{[55,56]} .1980 \sim 1996$ 年美国启动的“水生生物物种”计 划, 研究以跑道池系统为微藻培养的主要方式, 在 New Mexico 成功建成 $1000 \mathrm{~m}^{2}$ 的跑道池, 并取得了一定的成 果. 在实际应用中, 跑道池的不足逐渐显现出来, 因此在 设计跑道池时应合理确定影响微藻生长的参数, 主要包 括光和液厚.

首先, 光是跑道池培养微藻主要的限制因素, 设计时 可采用多种方式提高跑道池等开放式光生物反应器的 透光性, 例如增加藻液的流速、添加补充光源或提高表 面积/体积比. 流速是跑道池中防止藻细胞沉降以及使其 快速得到光照和 $\mathrm{CO}_{2}$ 的重要手段. 藻液的流速取决于液 厚和细胞的沉降速度, 根据不同的液厚及培养藻细胞的 特性, 确定适合的流速. 在一定范围内, 藻液的流速越高 越好, 可以增加藻细胞接触阳光的几率, 也可以防止贴壁 和沉降, 但这样会增加能耗, 一般跑道池中流速在 10 30 $\mathrm{cm} / \mathrm{s}$ 较合适 ${ }^{[57]}$; 另外, 还可以通过辅助的摚动装置, 来增 加藻液的湍流, 加速藻细胞上下运动的速率, 以达到增加 光强和 $\mathrm{CO}_{2}$ 浓度的作用 ${ }^{[58]}$. 在跑道池中增加人工光源也 能改善光照的问题, 但能耗过高, 从经济上是不可取的. 相比增加人工光源, 开放式光生物反应器中增加透明导 光箱是相对经济、有效的方法之一. 如图 1 所示, 在一个 开放式培养池中, 用一个矩形的透明箱将光传导到藻液 深处, 通过透明箱的散射作用, 增加微藻的光合效率和光 能利用率, 尤其在液厚比较大或藻细胞浓度比较高的情 况下,效果尤为突出,这种方法相当于提高了表面积/体 积比 ${ }^{[59]}$. 该研究还表明, 在透明导光箱体积一定的条件 下, 透明箱的个数越多培养效果越好. 用一开放池培养 小球藻, 如图 1 所示, 开放池中透明箱的体积相同, 其中 TRC3 得到的细胞浓度和生产率最大, 细胞浓度可以达 到 $3.745 \mathrm{~g} / \mathrm{L}$, 生产率可以达到 $0.34 \mathrm{~g} /(\mathrm{L} \cdot \mathrm{d})$, 比未添加该装 置时生物量提高了 $56 \%$. 尽管许多学者在跑道池等开放 式光生物反应器的光照问题上提出了很多方法与建议, 但目前仍没有行之有效的方案解决上述问题.

其次, 跑道池的液厚是影响微藻生长的另一个因素, 它直接影响光透率和微藻的光合效率, 藻液厚度一般为 $15 ~ 30 \mathrm{~cm}$. 在接种初期, 微藻浓度比较低, 光可以到达较 深的位置, 为微藻的光合作用提供充足的光照;随着微藻 的生长, 浓度越来越大, 光衰减严重, 虽然通过搅拌可以 使下层的藻细胞运动到上层, 但远不能满足微藻对光的 需要, 很难得到较高的生物量, 增加了后期微藻采收和加 工处理的难度及成本 ${ }^{[60]}$. 为了增加微藻的光合效率, 可 以通过减小液厚来实现. 以跑道池为例, 将跑道池某段的
底部提高, 高度差小于或等于 $5 \mathrm{~cm}$, 那么藻液在经过这个 区域时液厚就会变薄, 形成厚度为 $1 \sim 10 \mathrm{~cm}$ 的薄层区, 藻 液经过这段薄层区时可以进行旺盛的光合作用, 即使藻 液浓度比较高, 也能满足微藻对光的需要, 有利于提高藻 液浓度, 在一定程度上可以缓解跑道池等开放式光生物 反应器的光照问题; 但底部提高这部分区域的比例仍不 清晰 ${ }^{[61]}$. 跑道池内的液厚还影响建造成本. 当深度小于 $15 \mathrm{~cm}$ 时, 底部的斜坡就很难做到合适的角度, 而且在运 行中也容易出问题; 当深度过大, 例如高于 $50 \mathrm{~cm}$ 时, 建 造和运行成本会增加, 而且难获得较高浓度的微藻.

跑道池在培养中还存在一些其它的问题,如在开放 式培养过程中,微藻易受外界环境的影响, 培养条件控制 难度大, 包括 $\mathrm{CO}_{2}$ 、温度、光照、 $\mathrm{pH}$ 等. 以小球藻为例, 小 球藻对光强的适应范围为 4 30 klx, 而正午光强可达到 80 120 klx, 微藻浓度低时易发生光抑制, 微藻浓度高时 光照不充足. $\mathrm{CO}_{2}$ 是相对光照比较容易解决的一个限制 因素, 通过鼓气或与烟道气结合补气, 都能满足微藻生长 的需要. 虽然可以采用各种方法克服跑道池等开放式光 生物反应器的不足,但很难完全应用开放式光生物反应 器规模化培养微藻, 以获得足够的生物量进行生物质加 工处理.

\section{2. 封闭式光生物反应器}

开放式光生物反应器在微藻规模化培养中虽然具 有很多优势,但实际培养中也存在很多的问题.部分研究 者认为,封闭式光生物反应器是微藻规模化培养的发展 方向, 并开展了大量的研究, 研发出了多种封闭式光生物 反应器. 封闭式光生物反应器单位体积的生产力是跑道 池的 30 多倍 ${ }^{[62]}$, 大大简化后期微藻的采收和加工处理. 管式、柱式和板式光生物反应器是典型的封闭式光生物 反应器, 在此基础上还衍生出很多新型光生物反应器, 在 一定程度上克服开放式光生物反应器的不足. 表 2 列举 一些封闭式反应器培养微藻的研究结果, 无论是自然光 还是人工光源都可得到比较高的生产率, 但封闭式光生 物反应器在微藻规模化培养中也存在不足, 需要合理设 计进行弥补.

光径是封闭式光生物反应器的一个重要设计因素, 在一定范围内, 反应器的光径越小越有利于微藻的生长. 如表 2 所示, 光径最小的是薄层反应器, 得到的生产率最 大. 反应器的光径, 也可以理解为藻液厚度, 直接影响藻 细胞随机接触光的几率, 光径越小, 微藻吸收的光照越 多, 生长越快; 反之由于光衰减严重, 微藻之间的遮挡比 较严重, 从而导致微藻生长比较缓慢, 也容易滋生病虫 
害. 在直径为 3 和 $6 \mathrm{~cm}$ 两种不同光径下培养两种绿藻, 3 $\mathrm{cm}$ 光径下比 $6 \mathrm{~cm}$ 光径下得到的细胞干重高, 最大可提 高 $50 \%{ }^{[73]}$. 光径不但影响微藻的生长, 还影响油脂含量. 在 $3 \mathrm{~cm}$ 光径下培养时, 绿藻的总脂含量随培养时间的延 长明显增加; 而 $6 \mathrm{~cm}$ 光径下培养时, 绿藻的总脂积累时 间滞后, 直到培养后期总脂含量才出现了明显的增加 ${ }^{[73]}$. 两株南极绿藻 (Pyramidomonas sp. 和 Chlorophyceae L-4), 在不同光强下培养, 其总脂含量随着光照强度的升 高显著降低, 其中 Pyramidomonas sp. 的总脂含量由 $14.17 \%$ 下降到 5.94\%,Chlorophyceae L-4 由 $14.17 \%$ 下降 到 $3.40 \%{ }^{[74]}$. 光径对微藻油脂含量的影响可能有两方面 的原因; (1) 光径小微藻生长速度快, 未进行营养补给或 营养补给不及时, 就会形成胁迫, 提高油脂含量; (2) 由于 光径小, 藻细胞获得的光照强度大, 容易发生光抑制, 影 响微藻生长和油脂积累.

下面对几种典型的封闭式光生物反应器进行介绍.

管式光生物反应器根据形状及放置方式可分为垂 直管式反应器、水平管式反应器、倾斜管式反应器、 $\alpha$ 型 管式反应器等, 孔径范围一般为 $2.5 \sim 5.0 \mathrm{~cm}^{[64,75]}$. 管内容 易形成高溶氧, 限制了管子的长度, 不利于提高培养总体 积. 为了提高总体积, 同时提高空间利用率, 常采用集光 管的排列方式, 减少了土地占用面积, 增加了光的利用 率, 但运行难度大、成本高. 在管式反应器培养微藻的过 程中, 管壁的清洗非常困难, 藻细胞贴壁后严重影响光透 性, 目前以机械清洗为主, 暂无其它有效的清洗方法. 虽 然管式反应器存在很多不足, 但用它培养微藻可以提高 生产率, 得到较高浓度的微藻, 在表 2 中列举的管式反应 器中, 最大生产率可达到 $830 \mathrm{mg} /(\mathrm{L} \cdot \mathrm{d})$. 在管式反应器中, 除了光径, 其它因素对微藻培养的影响也十分重要, 需合 理设计各种参数才能提高生产率, 如培养体积比例. 用 螺旋管和直管培养 Chlorella vulgaris, 两者光径和培养 条件相当 (螺旋管反应器直径 $3.12 \mathrm{~cm}$, 直管反应器直径 $3.2 \mathrm{~cm})$, 直管反应器中的最大生产率 $(600 \mathrm{mg} /(\mathrm{L} \cdot \mathrm{d}))$ 是螺 旋管反应器中的 15 倍 $(40 \mathrm{mg} /(\mathrm{L} \cdot \mathrm{d}))^{[63,66]}$, 其主要原因是 由于螺旋管反应器培养体积为 $230 \mathrm{~L}$, 处于螺旋管中进行 光合作用的藻液体积为 $150 \mathrm{~L}$, 其余 $80 \mathrm{~L}$ 藻液在储液箱 中, 严重影响了整个反应器的生产率.

柱式光生物反应器主要类型有鼓泡式、气升式和摚 拌式, 制造材料通常使用玻璃、聚乙烯等透光性能好而 且成本低的材料 ${ }^{[76,77]}$. 与传统的发酵罐类似, 主要区别在 于柱式光生物反应器需要在内部或外部设置光源. 鼓泡 式和气升式的区别在于后者内部设有导流筒, 底部通气
带动液体循环达到混合的目的. 搅拌式光能利用率比较 低, 由于先天结构的问题, 搅拌器占用反应器一定的空 间, 设置内光源有困难, 而外光源又受表面积的限制, 藻 细胞生长速率慢. 柱式光生物反应器一般高 2 2.5 m, 直 径 $20 \sim 50 \mathrm{~cm}$, 反应器建设成本较低, 培养时使用的柱子可 以循环利用, 但光利用率不稳定, 藻浓度对光透率的影响 大, 在培养高浓度微藻方面存在困难. 中国石化在北京 微藻培养基地采用柱式光生物反应器培养微藻, 如图 2 所示, 接种初期微藻生长快; 随着藻浓度的增加, 光成为 主要的限制因素, 影响微藻的培养浓度.

板式光生物反应器, 主要有两种水平和坚直放置方

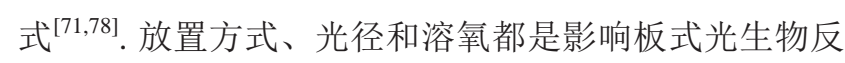
应器培养效率的重要因素. 水平放置时, 反应器接触光 的表面积大、微藻光合效率高, 但是空间利用率低、光 利用率低, 而且容易发生光抑制; 坚直放置时, 可以提高 空间和光的利用率, 但对反应器材质强度要求比较高, 成 本较高. 有些研究者认为, 板式光生物反应器的放置角 度应该是随太阳而变化的, 虽然具有倾斜角度的平板可 以获得更多的光照, 但是在实际培养过程中, 垂直板式光 生物反应器中藻细胞的光合效率比有角度的反应器中 的要高 $20 \%$. 这可能是由于具有角度的板式光生物反应 器能获得较多的光照, 光强过高, 不利于微藻光合作用的 进行 ${ }^{[79]}$. 板式光生物反应器的光径 (内部厚度)一般为 $1.5 \sim 3.0 \mathrm{~cm}$, 限制了培养体积, 需权衡体积产率、面积产率 和反应器产率的关系. 研究表明, 在一定范围内, 板式反 应器的培养效率随着光径大小的减小而增加, 如表 3 所 示. 随着光径的减小, 板式反应器的体积产率逐渐增加, 在 $1.3 \mathrm{~cm}$ 时达到最大值 $0.846 \mathrm{~g} /(\mathrm{L} \cdot \mathrm{d})$, 而板式反应器的面 积产率随着光径的减小先增加后降低, 这主要是由于虽 然反应器单位体积的产率增加了, 但由于光径减小, 单位 面积上培养的微藻总体积减少, 不利于提高板式光生物 反应器的生产率 ${ }^{[71]}$. 溶氧是板式光生物反应器存在的另 一个问题, 高溶氧限制了反应器的培养体积, 常用外加动 力或换气的方法控制溶氧, 且同时达到传质、混匀和散 热的目的. 达到相同的传质效果, 板式光生物反应器的 能耗较低, 为 $53 \mathrm{~W} / \mathrm{m}^{3}$, 而气泡柱式和管式光生物反应器 的分别为 40 和 $2400 \sim 3200 \mathrm{~W} / \mathrm{m}^{3[80]}$.

薄层光生物反应器属于封闭或半封闭式光生物反 应器, 如图 3 所示. 通过外加动力将藻液注入倾斜流道 内, 在初始动力和重力的作用下, 藻液在流道内形成有利 于光合作用的薄层区. 该反应器倾斜槽的斜率 $1.1 \% \sim 2.5 \%$, 藻液流速 30 150 cm/s, 藻液厚 $5 \sim 18 \mathrm{~mm}^{[81]}$. 
在面积 $224 \mathrm{~m}^{2}$, 长 $28 \mathrm{~m}$, 倾斜率 $1.7 \%$ 的薄层光生物反应 器上培养小球藻, 藻液厚 6 7 mm, 小球藻的平均干重浓 度可达到 $38.2 \mathrm{~g} /\left(\mathrm{m}^{2} \cdot \mathrm{d}\right)$ 或 $4.3 \mathrm{~g} /(\mathrm{L} \cdot \mathrm{d})^{[72,82]}$, 高于管式、板式 和柱式光生物反应器中的产率. 薄层光生物反应器在流 道内液厚较薄, 因此不适合在流道中补充 $\mathrm{CO}_{2}$, 特别是当 与炼厂 $\mathrm{CO}_{2}$ 减排相结合时. 为了提高补充 $\mathrm{CO}_{2}$ 的利用率, 一般选择液厚较大区域进行补气, 在薄层光生物反应器 中, 流道与流道连接处以及循环液体收集槽内液厚较大, 而且从流道中流回的藻液光合作用旺盛, $\mathrm{CO}_{2}$ 消耗快, 适 合在这些位置补充 $\mathrm{CO}_{2}$. 但该装置从研发到现在十年多 内并没用实现大规模培养, 说明其还存在一些不足. 首 先是液厚, 液厚应随藻液浓度的变化而变化, 培养初期藻 液浓度较低时, 应适当增加液厚, 随着藻液浓度的增加, 逐渐减小液厚; 其次就是总生物量较低, 由于薄层液厚 较小, 总培养体积偏低, 虽然可以得到高浓度的藻液, 但 总生物量较低. 尽管薄层光生物反应器存在一些不足, 然而薄层的理念为培养高浓度微藻开辟了新思路, 在弥 补已有薄层光生物反应器不足的基础上, 很多研究者研 发出了多种新型微藻光生物反应器. 荣峻峰等 ${ }^{[83]}$ 发明了 一种微藻培养装置, 该装置包括藻液存储单元、藻液输 送设备和藻液导流面. 输送设备将存储单元的藻液送至 导流面上, 藻液在导流面上形成较薄的液层, 通过参数控 制液层的厚度及流速, 微藻在导流面上进行光合作用, 最 后藻液通过导流面流回存储单元, 形成一个循环通路. 该装置适合于大规模、低成本、高效率的培养微藻. 低 落差开放池也利用了薄层的思路, 为跑道池等开放式光 生物反应器提供薄层区域, 当藻液经过此处时充分吸收 光照, 能提高微藻的光合效率, 增加跑道池等开放式光生 物反应器的培养浓度 ${ }^{[61]} .2011$ 年美国一专利也体现了薄 层的思路 ${ }^{[84]}$, 如图 4 所示, 储存箱内的藻液在重力的作用 下流入下面具有倾斜角度的平板 (multi wall sheets) 中, 在平板上形成薄层区进行光合作用, 最后流入藻液收集 箱中 (如果藻液浓度过高, 需要提供外加动力推动藻液 流动), 平板上面有透明的覆盖物, 可以过滤掉紫外线, 也 可以防止水分蒸发, 底部表面涂反光材料, 提高微藻光合 效率.

以上介绍了多种微藻光生物反应器, 这些光生物反 应器克服了开放式跑道池的某些不足, 有利于实现微藻 的规模化培养, 但又存在一些新的问题, 阻碍了其在微藻 规模化培养中的应用, 有待改进. 在满足微藻生长对光、 $\mathrm{CO}_{2}$ 、营养盐等需求的前提下, 适用于微藻规模化培养的 光生物反应器应趋向结构简单、操作简便、成本低廉、
过程能耗低的方向发展, 并且根据培养地点自然环境的 不同研发和采用合适的光生物反应器.

\section{3. 多种光生物反应器结合}

单一光生物反应器往往不能满足微藻规模化培养 的需要, 很多研究者将相同或不同的反应器结合, 形成互 补以扩大培养规模. 如开放式与封闭式反应器之间的结 合、自养与异养的结合. 开放式光生物反应器培养体积 大但微藻浓度低, 封闭式光生物反应器能提高微藻浓度 但培养体积较小. 将两者结合起来可以相互弥补不足, 有利于提高微藻规模化培养的体积和浓度, 其结合方式 有两种: (1) 将开放式反应器作为藻种供应装置, 为封闭 式反应器提供低浓度藻种, 充分发挥封闭式反应器可以 得到高浓度微藻的优势; (2) 将开放式与封闭式反应器 糅合在一起, 通过封闭式反应器提高微藻的浓度, 最终提 高生物量. 这两种结合一个重要的意义是减少微藻在开 放式反应器中的时间以减少受外界污染的危险. 微藻在 营养胁迫下会增加细胞内油脂含量, 那么将封闭式与开 放式反应器结合可以得到高油脂含量、高浓度的藻液. 首先在封闭式反应器中得到高浓度的微藻, 然后再将其 转入开放式反应器中进行营养胁迫, 增加藻细胞的油脂 含量. 韩春梅等 ${ }^{[85}$ 根据微藻生长的不同阶段采用不同的 反应器, 将开放式与封闭式反应器相结合为同心圆反应 器, 由内到外共有三级反应器: 第一级是以人工光源为 主的封闭式反应器, 微藻保持在对数生长期, 为后两级培 养提高藻种; 第二级是以自然光为主、人工光为辅的封 闭式反应器, 微藻处于对数生长期或稳定期, 用来提高微 藻生物量; 第三级是开放式或封闭式反应器, 对微藻进 行营养胁迫以提高油脂含量. 刘天中等 ${ }^{[861}$ 将跑道池与 板式 (或气泡柱式) 光生物反应器相结合, 将跑道池中的 部分藻液原入板式 (或气泡柱式) 反应器的底部, 再通过 上部的管道流回跑道池进行循环, 可以将微拟球藻 (Nannochloropsis) 生物量提高 $75 \%$.

\section{4. 计算流体力学 (CFD) 模拟}

微藻光生物反应器的研发是微藻生物能源产业生 物质来源的关键环节, 传统的研发手段耗时且费用高. 随着计算机技术的进步, CFD 技术由于耗时短、成本低 和效率高成为各类反应器设计、优化和规模化的方法, 具有非常好的应用前景. Sato 等 ${ }^{[87]}$ 利用计算机模拟微藻 生长, 计算出微藻培养过程中溶氧释放、 $\mathrm{CO}_{2}$ 消耗以及微 藻生长状态, 还优化出适合不同藻种生长的环境条件, 这 种模拟方法比参考文献中的数据更具有针对性. 为了适 应不同地区的培养环境, 利用计算机模拟地理位置、太 
阳变化和板式光生物反应器放置角度三个因素对单个 或平行放置的板式反应器微藻生物量产率的影响 ${ }^{[88]}$. 藻种为 Phaeodactylum tricornutum 和 Thalassiosira pseudonana, 地理位置为荷兰、法国和阿尔及利亚, 单个 板式反应器培养时, 在荷兰培养时微藻年生物量最大. 多个反应器联合时, 遮挡和光散射 (板与板之间) 是主要 的影响因素, 还发现反应器的放置方位对生产率的影响 也很大.

光生物反应器的设备成本及过程能耗是微藻生物 能源经济可行性的一个主要评价指标, 也是制约微藻生 物能源发展的一个重要因素. 利用计算机模拟光生物反 应器及培养过程, 既可以降低光生物反应器的研发成本, 缩短研发周期, 又可以对光生物反应器的过程能耗进行 评估, 在可行的基础上还可以进一步模拟与其他能源相 结合的效果, 如风能、电能 (利用微藻生物质发电) 等, 形 成一个完整的、循环的培养体系. 另外, 微藻规模化培养 的经济性, 还应考虑其带来的社会效益. 首先可用烟道 气中的 $\mathrm{CO}_{2}$ 培养微藻, 降低温室气体的排放; 其次可利 用废水培养微藻, 将废水中的有机物和无机物转化为有 价值的生物质. 这样既能保护环境又能降低废气废水处 理的成本, 不但降低了微藻规模化培养的成本, 而且赋予
其社会价值, 将大大推进微藻生物能源的发展.

\section{5. 结束语}

微藻生物能源具有广阔的应用前景, 但目前仍处于 探索阶段, 其中微藻规模化培养是微藻生物能源技术中 的关键环节. 需要系统研究藻种选育、代谢机理、培养 条件以及光生物反应器等因素对微藻规模化培养的影 响. 我们认为, 在微藻规模化培养过程中, 以下几个方面 需深入研究: 建立规模化培养藻种的选育规程, 通过逐 级笁选获得理想的优质藻种; 研究藻种的代谢机理, 通 过控制培养条件和开发高效、低成本、易实施的油脂诱 导工艺促进微藻生长及提高油脂含量, 同时开发其它具 有价值的副产品; 与工业烟气减排和污水处理结合, 研 究微藻对烟气中 $\mathrm{NO}_{x}$ 和 $\mathrm{SO}_{x}$ 的代谢规律, 建立工业烟气 减排和污水处理与微藻培养结合的工业示范基地, 把解 决微藻规模化培养的经济问题与环境保护相结合; 围绕 “设备成本与过程能耗”两个核心问题, 开发微藻规模化 培养的低成本培养模式, 研发培养高浓度微藻的光生物 反应器, 开展连续规模化培养的实际验证, 突破“规模化 培养”这一影响微藻生物能源技术能否产业化的最关键 的难题. 